Article

\title{
An Assessment of Urban Development and Control Mechanisms in Selected Nigerian Cities
}

\author{
Barnabas W. Qurix ${ }^{1}$, Lawrence C. Edomwonyi-Otu ${ }^{2 *}$ and Danjuma Jise ${ }^{3}$ \\ 1Bingham University, Abuja, Nigeria (qurexs@yahoo.com) \\ 2Delta State University, Abraka, Nigeria (uceclce@ucl.ac.uk, edomwonyi-otu@delsu.edu.ng) \\ ${ }^{3}$ Nigerian Defence Academy, Kaduna, Nigeria (jised@yahoo.com) \\ *Correspondence: uceclce@ucl.ac.uk; Tel.: (+234 810580 5383)
}

\begin{abstract}
The paper makes a critical assessment of urban development in Nigeria against the backdrop of a rapidly changing population and growth rate. The Authors interrogated the effects of development control- mechanisms through the lenses of identified social anomalies in three selected pilot cities of Nigeria (Kaduna, Abuja FCT, and Lagos). Thematic areas examined include, the state of critical infrastructure, population dynamics, urban sprawl, city polarization, transportation, waste management systems, security/crime and economics. The Authors identified structural transformation of three Nigerian cities with focus on the causes and attendant consequences on urban development. The study found that urban growth has over-stretched the state of critical infrastructure in the cities and the mechanisms of development control seem ineffective in stemming unregulated growth, compromises and unplanned 'development'. The paper noted that the impact of these developments has overstretched the state of critical infrastructure with far-reaching consequences. The authors conclude with some recommendations for strategic planning and sustainable development strategies aimed at mitigating the problems of urban development in Nigeria.
\end{abstract}

Keywords: development controls; physical planning; regulations; cities; urban development; polarization; infrastructural deficit; Kaduna; Abuja; Lagos

\section{Introduction}

Urban population has risen steadily in Nigeria over the last 20 years as revealed by census figures. For example, as at 1991, Nigeria's population was 88.9 million; in 2006, it was 140 million and in 2010, it was 163 million. In 2016 the population rose to 182.3 million according to National Population commission (Ogunleye et al., 2018). Correspondingly, poverty levels have continued to rise; 42.5\% in 1992, 54.4\% in 2004 and 69\% in 2010 (NBS 2012). Meanwhile the number of urban centers grew from 56 to 185 between 1953 and 1963 when Nigeria became a Republic. It is estimated that about $48.2 \%$ of the country's population now live in urban areas and this could grow to $60 \%$ by 2025 . With a projected population growth rate of $5.8 \%$, Nigeria has more than 40 cities with a population more than 1 million. (Ayedun, et al., 2011). Indeed, Lagos alone was estimated to have a population of nine (9) million in 2006. Interestingly, while the rate of growth of the rural population had decreased from $1.6 \%$ in 1990 to $1.1 \%$ in 2014, the rate of growth in urban populations decreased from $4.6 \%$ in 1990 to $4.0 \%$ in 2010 and rose to $4.5 \%$ in 2014 . It is vital to plan with increase in population 
growth, because when unplanned and uncontrolled, it would have adverse effect on the environment as a great consequence.

In 2010, the National Bureau of Statistics (NBS) noted that percentage of rural population of the Nigerian population decreased from $64.7 \%$ in 1990 to $50.2 \%$ in 2010 and rose to $53.1 \%$ in 2014 indicating a slight decrease (NBS, 2015). This means that there is a high population of urban dwellers in Nigeria more than was previously thought. It is believed that richer countries have higher urban population as against poorer countries while coastal countries have higher urban population than landlocked countries (ADB Group). According to a world city report by World Bank, Africa has 17 of the world fastest growing cities. Generally, urban areas have been identified as important economic centers probably due to availability of infrastructure, metropolitan facilities and propensity for economic activities. Nevertheless, the potential for economic activities remains largely untapped. Weak governance structures and lack of political will have been identified to be responsible. It is expected that urban development activities would escalate with attendant consequences. At this point, we may wish to define urban development as a systematic increment in infrastructure, metropolitan facilities, socio- economic activities and appropriate governance structure for the purpose of improved quality of life of the urban inhabitant.

Against this backdrop therefore, it is contended herein, that the inability of urbanization to produce tangible urban development is responsible for stunted or skewed growth of cities. Some of which are only bloated with high populations but heavily loaded with slums, blighted areas and uncontrolled development as well as insecurity. The control mechanism for urban development existing in many states in Nigeria is basically the Nigeria Urban and Regional Planning Law (NURL) Decree 88 of 1992, which has been reviewed in 1998 and has been adapted for use. The Federal Capital Territory and Lagos have Development Control Manuals produced from the NURL. A careful look at them suggest that there is a concentration on physical development; particularly building and road. Although broad policy frameworks are drawn for other aspects of development such as traffic, telecom installations, and open spaces, the absence of details still leaves many gaps in implementation. In the light of the rapidly changing urban landscape and the emergence of new social and economic realities, it becomes imperative to review the existing regulations that govern the development of our cities.

\subsection{Aim}

The aim of this paper, is to review the current challenges of urban development in Nigeria and the adequacy or otherwise of existing regulations in controlling and defining the process. Three cities have been selected for review, these are Kaduna, Abuja and Lagos.

\subsection{Justification}

The basis for this is that the cities have well defined socio-economic histories, high populations and functional Development Control Agencies. Besides, their cosmopolitan outlook sets them apart, from other Nigerian cities as these cities are inhabited by various ethnic nationalities which geographically represents; Northern Nigeria (Kaduna), Central Nigeria (Abuja) and Southern Nigeria (Lagos) respectively. In doing this, various relationships are examined, among such are infrastructure and social behavior, open space and security, economic activity, crime, mobility and functional output. It is not in doubt that a study of these cities would generate adequate information 
for a discourse that is representative of Nigeria as well as present a balanced socio-economic platform on which urban development could be viewed.

\section{Urbanization and Urban Development in Nigeria}

The proportion of people living in urban areas in Nigeria has increased steadily since independence. Qurix (2017) notes that by 1970, Nigeria had possibly one of the fastest urbanization growth rates in the world. In 1986, the growth rate was estimated to be about $6 \%$. It rose to $40 \%$ in 2010 (Qurix 2017). The establishment of industries during the oil boom years and the relatively cheap means of transportation such as the railways facilitated a pull factor or movement to the cities. In the Northern part of the country, commerce and trade contributed in the growth of cities. During the precolonial era, Kano and Katsina played prominent roles as trade and industrial centers. Kano emerged more prominent from the 19th century with establishment of many industries such as textiles and dying. Later, Kano played a prominent role as a center for commercial activities associated with the groundnut pyramids of the post-colonial era in Nigeria. Other cities which acted as magnets include Sokoto, where companies of British, American and French origins were established in the 20th Century (Iweze 2015). Between 1973 and 2009, the increase in urban land use stood at 13,296 ha (207.4\% increase) (Akpu et al., 2017).

It is important to state that infrastructural development such as roads, and railways contributed largely in the establishment of these cities. Kaduna on the other hand had served as the capital city of the colonial administration and subsequently as the capital of northern Nigeria. Kaduna is an important geographical area which is highly significant in the political life of northern Nigeria (Bununu et al., 2015). It attracted people from various parts of Nigeria because of its administrative significance and its central and strategic location in the north, and in the Nigerian context. An aerial view of a section of Kaduna metropolis is shown in Figure 1.

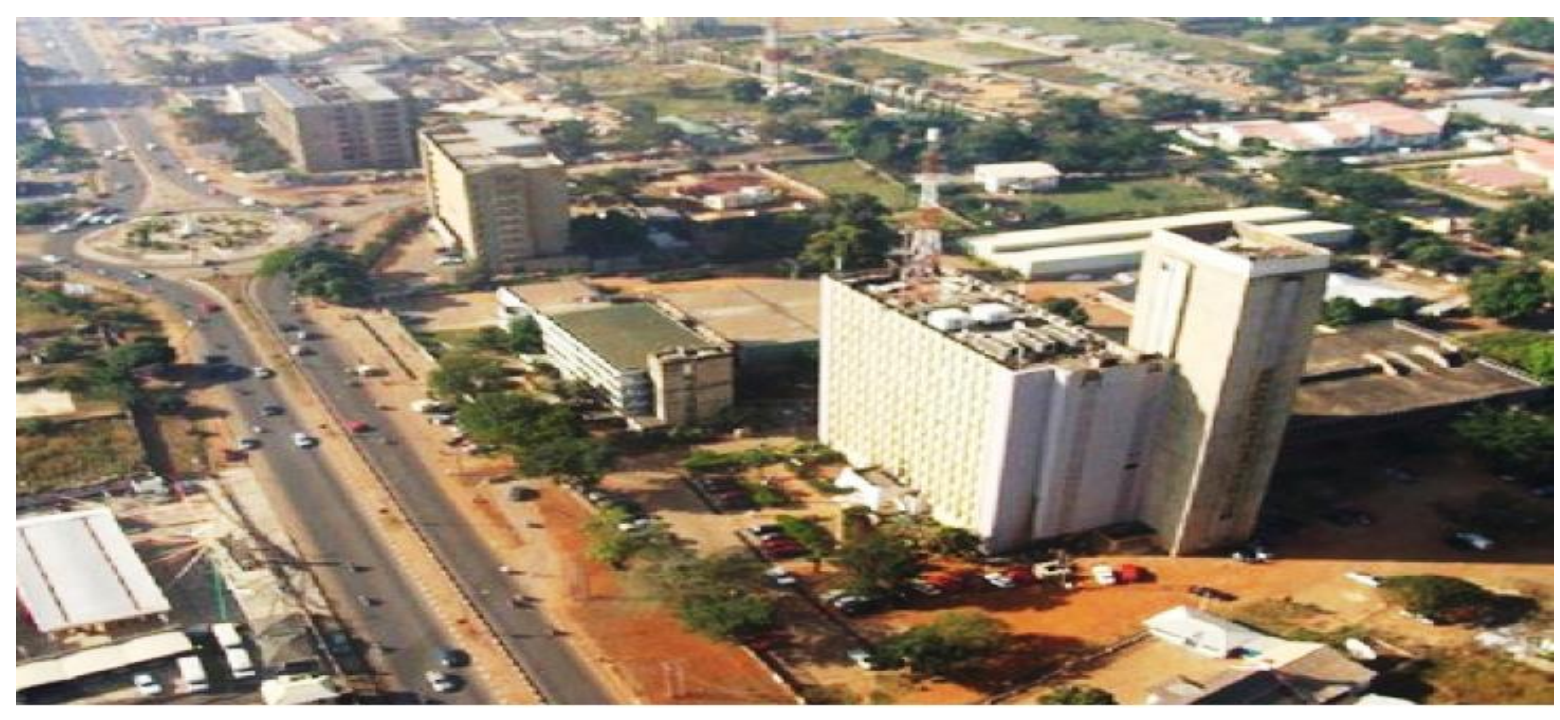

Figure 1: NEPA Round About Ahmadu Bello Way Central Area Kaduna. As a Planned area. Source: Researcher's field Photo

Kaduna was set up from an almost virgin area as a garrison town and as the capital of northern protectorate as far back as 1917. The town was deliberately planned to have a balance of various functions i.e. as a geostrategic and political hub, being the capital of the north with the primacy of the later in Nigeria's political game theatre. More to it, Kaduna probably is home to more military 
formations and organizations than any other states or region in Nigeria, having been earmarked from the onset as a military garrison and industrial town. This was backed by massive infrastructural development such as well laid out roads, houses, open spaces (green areas) and adequate water supply. Thus, the population of Kaduna grew from 20,000 in 1951 to 250,000 in 1963, 1.3 million in 1991 and over 3 million in 2006. On the basis of projections using the baseline of the 1991 and 2006 census figures, it is estimated that Kaduna is home to over eight (8) million inhabitants as at date (National Population Commission 2006). Kaduna Metropolis alone has joined the league of cities in Nigeria with over a million inhabitants. It is worthy of note here that the textile industries played a major role in attracting people to Kaduna until their collapse in the late nineties. This role was however taken over by the Kaduna refinery which was established in 1979. Thus, as at date, Kaduna has significant populations made up of former textile workers, refinery workers, civil servants and retired military personnel; all in their second or third generations. The fast growth rate alongside inadvertent expansion of the city had led to several negative consequences (Usman et al., 2017).

When we turn to the south, Lagos represents a clear example of the urbanization process in Nigeria. By 1960, Lagos had a population of 400,000 and grew to over fourteen (14) million in 2020 (NBS, 2015; Populationstat.com, 2020). When the Lagos Central Planning Scheme was drawn in 1957, the area called Marina was a slum and the scheme anticipated its clearance and re-development; existing roads were to be widened in anticipation of the rising population. The plan set out guidelines for building heights, pedestrian passengers and construction of massive infrastructure (roads, bridges and housing). Between 1962 and 1972 massive building construction of both commercial and residential structures increased but the laying of satisfactory piped sewage disposal system was lacking, and this remained a serious challenge even to the eighties and early nineties. As a coastal city, Lagos derived immense prosperity from external trade in goods, cars and oil (Duthiers and Kermeliotis, 2012; Price and Vojinovi, 2011).

As Nigeria's Federal Capital city until 1991, Lagos accommodated large population of civil servants as well as trade merchants from Eastern Nigeria. As economic prosperity of Nigeria reached its height in the seventies, the population of Lagos exploded, and infrastructure became overstretched. One way to deal with this was to move the Federal Capital to Abuja; of course, this only partially helped, as Lagos continued to function as the economic nerve center of Nigeria. Besides, population overflow from Lagos to other neighboring states was rather slow until recently, perhaps in the last twenty (20) years. By current realities, Lagos might have provided a fair template worthy of emulation at least in the last ten (10) years or more. The quality of life has also remained reasonable as economic activities remained high. Even crime rate appears to be dropping according to a recent declaration by the Inspector General of Police. It is therefore fair to say that the urbanization process in Lagos has produced a definite urban development pattern in the last ten (10) years (Dano et al., 2020; Aluko, 2010). Figure 2 shows an aerial view of Ikeja metropolis, a modernized and developed part of Lagos. 


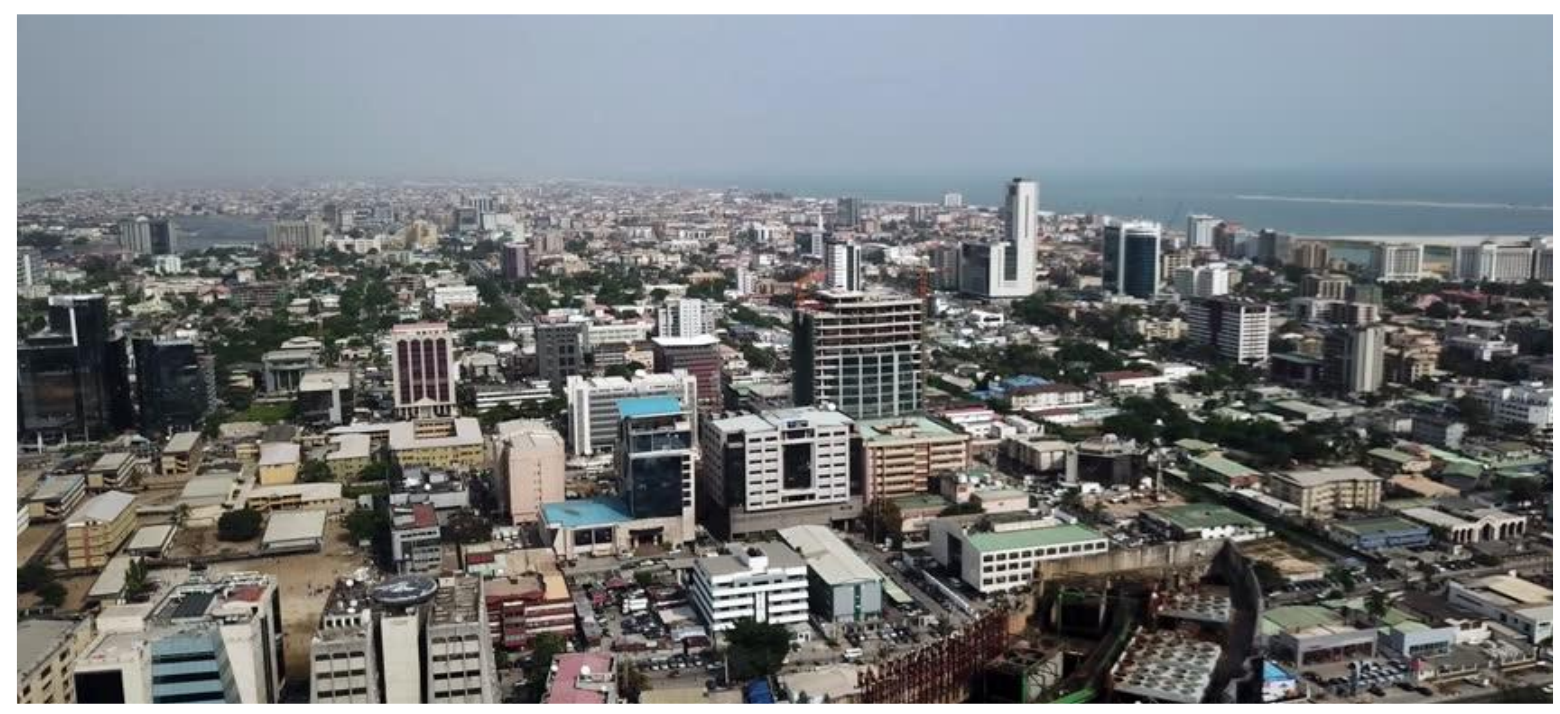

Figure 2. Ikeja, Lagos. Source: Landsat imagery

One of the factors that have been identified to be responsible for movement to the cities is the apparent lack of conscious effort by governments to develop the rural areas and provide basic amenities. This forces the rural dwellers to migrate (Ayedun, 2011). At best, the rate of growth in rural areas is so slow that it exposes the inhabitants to various forms of vulnerabilities including insecurity owing to uncontrolled development.

Turner and coworkers (Turner II et al., 1990) among others, believe that urbanization is a major driving force of urban growth and environmental change. They showed that the earth is transformed by human action and maintains that urbanization - both as a social phenomenon and a physical transformation of landscape is one of the most powerful, irreversible and visible anthropogenic force on earth and the major force behind urban growth in developing world. Development strategists from all shades of the political spectrum agree in this respect, although they differ considerably in their assessment of the consequential benefits of such change. Figure depicts some poor sights in Kaduna, a development deficit and an evidence of unorganized urbanization and migration. Urbanization and more particularly, the urbanization process, thus refers much more than simple population growth and involves an analysis of the related economic, social and political transformations. That is why Drakakis (1987), thinks that the dimension of urban population growth only forms an essential background to the distribution and extent of the urbanization process.
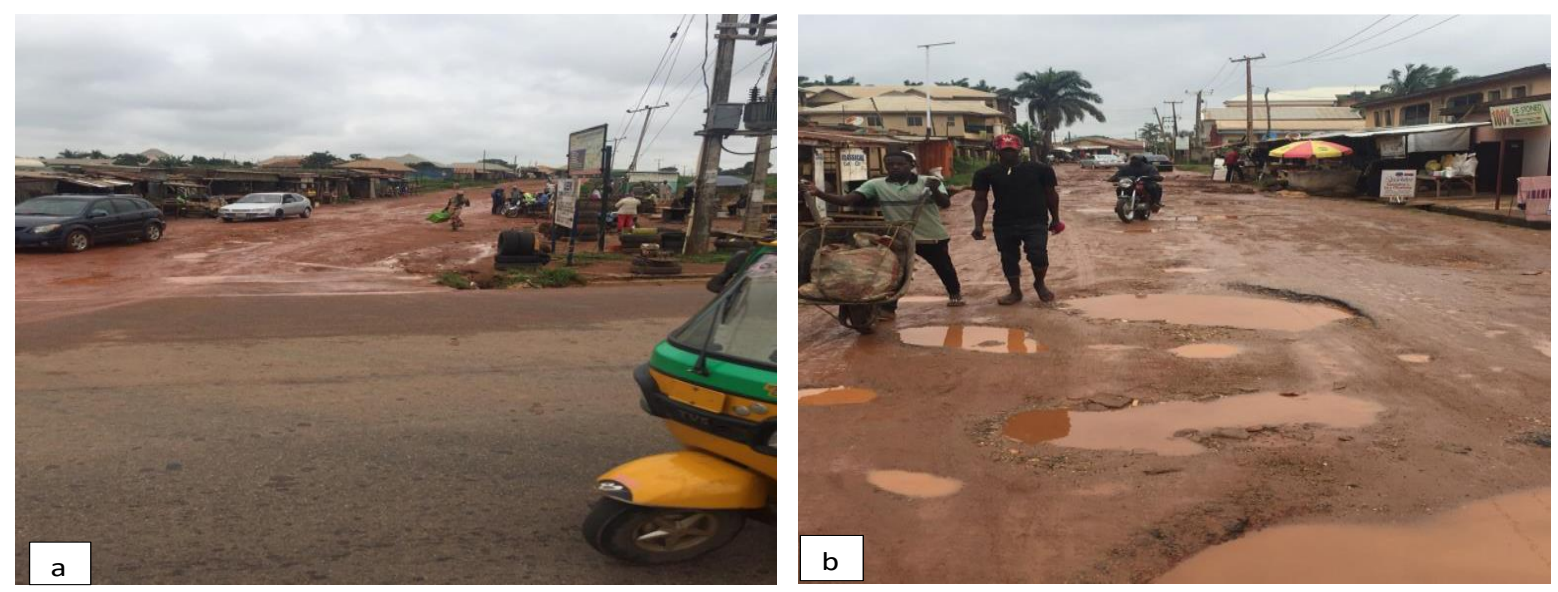

Figure 3 (a \& b). Janruwa Junction, Kaduna: A sight of infrastructural deficit within the city (Field photograph) 


\subsection{Uncontrolled Development, Contraventions and Correctional Measures}

There is a wide scale contravention that has been witnessed in the last twenty (20) years. It takes the form of indiscriminate change of land use resulting to the construction of commercial buildings side by side residential buildings or conversion of residential buildings into recreational facilities or hospitality outlets. Many areas of Kaduna such as Barnawa, Unguwan Rimi, are notorious for this. In Abuja, Kubuwa, Nyanya and Karu are examples of places where this is visible.
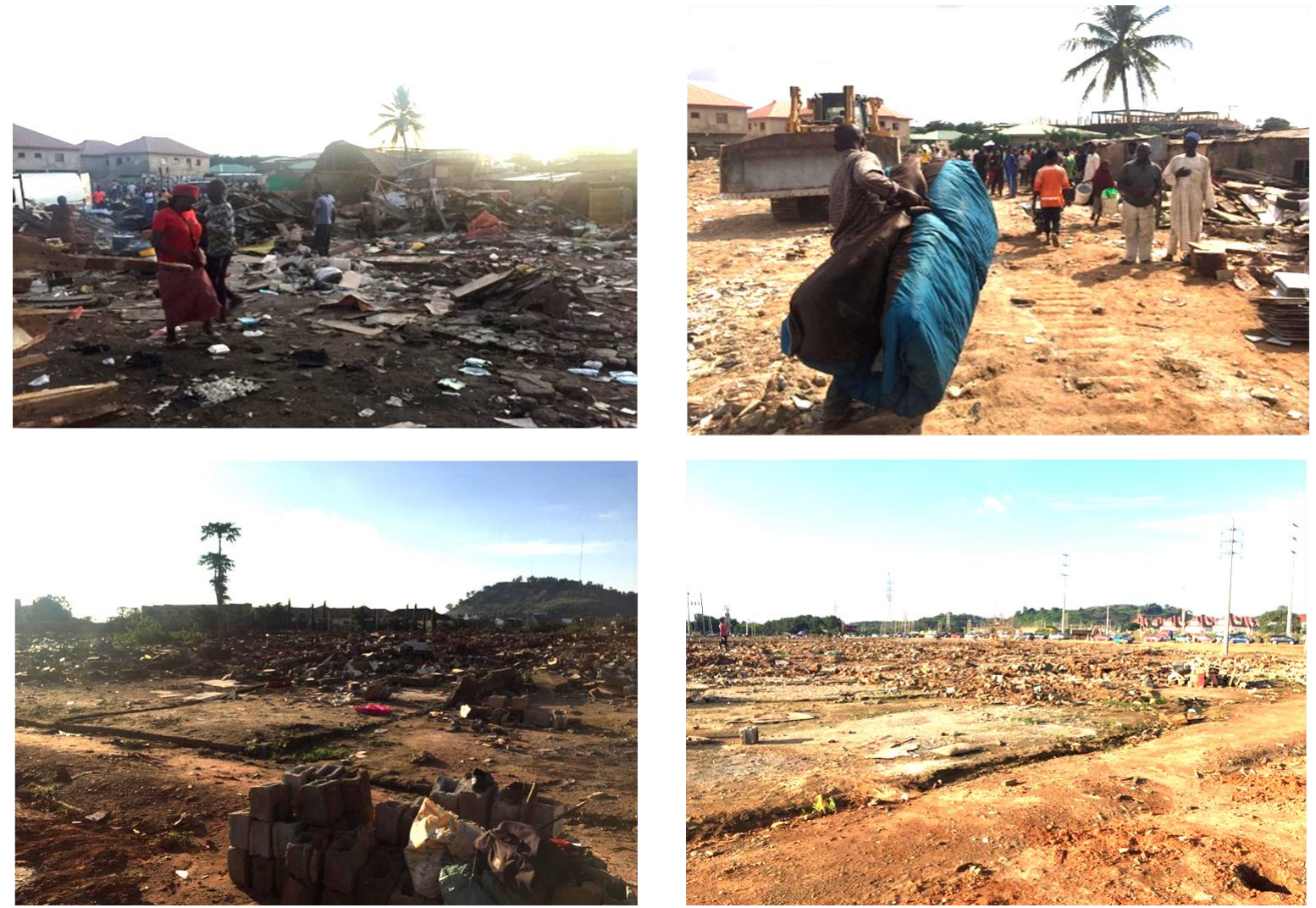

Figure 4. Demolished make-shift residential and commercial arrangements in Apo and Utako, Abuja. (Field photographs)

In Abuja a ministerial directive to demolish buildings and open spaces or drainages was carried out in 2008. In Kaduna, cases of farmlands which are converted to lay-outs for building purpose are prevalent in places such as Rigasa, Kinkinau and Unguwar Muazu. Usually, the quality of houses built on such lands is inferior and less than the ideal. The make-shift market in Apo was demolished to correct planning infractions. Figure 4 gives pictorial view of these correctional measures. This attests to the effectiveness of development control mechanism and the strong political will to translate plans into actions. It remains to be seen though what measures are put in place in the immediate term to provide succor to affected residents or users of demolished areas. It would seem a pro-poor approach and one that acts with a human face, is still far from sight (Nekabari and Aguiyi, 2012; Oluwafemi et al., 2018).

\subsection{Blighted Areas}

Another glaring phenomenon of the urban center is the blighted areas. There is hardly any conscious regulation for the redevelopment of blighted areas such that even along main streets one could notice several sights of blight phenomena. Ahmadu Bello Way Kaduna has several blighted areas which are relic of colonial buildings; Lagos Island has many. In the case of Lagos, it appears 
safer to demolish some of the multi-storey buildings with weak structures, finishes and dysfunctional roofs at the interface between the mainland and Island areas when visualized along Carter Bridge. The phenomenon of juxtaposing informal blighted structures side-by-side with modern planned structures is a practice that must be outrightly banned (Jelili et al., 2020). Moreover, blighted areas as seen in Kaduna (Figure 5) should be marked for urban renewal by the appropriate authorities (Wendell, 2003).
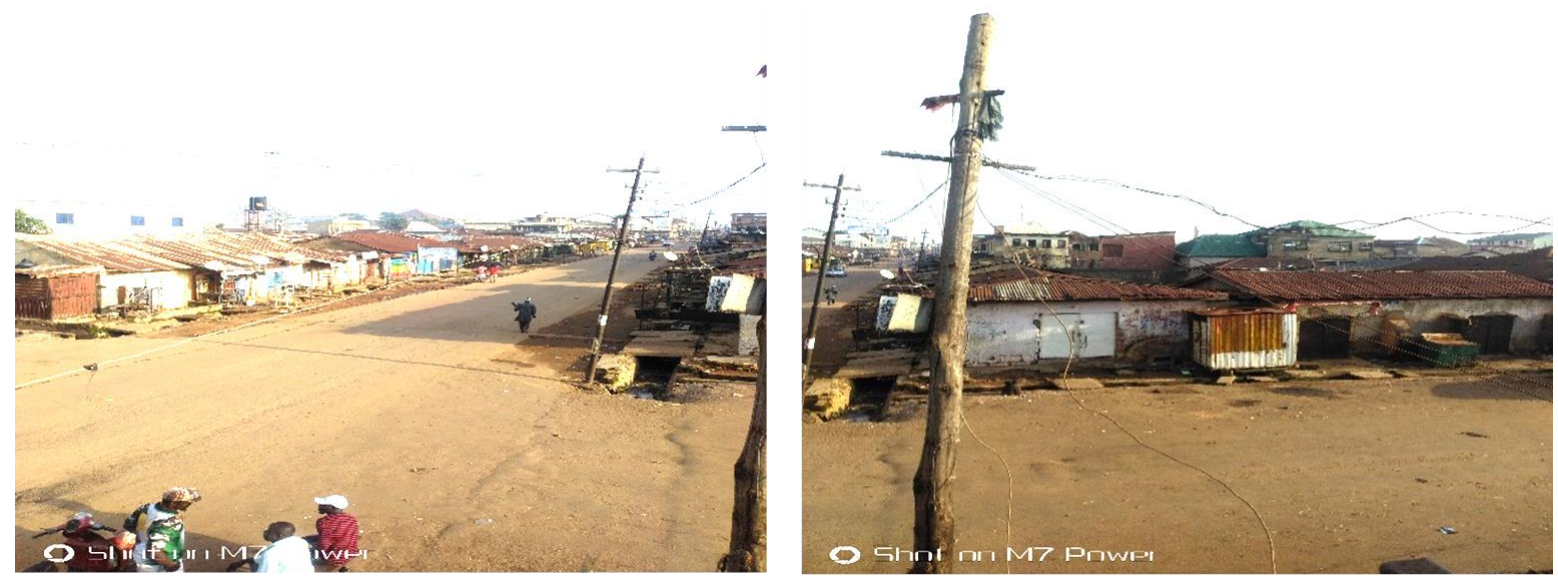

Figure 5. Some blighted areas in Katsina road, Kaduna. (Field photographs)

From aerial view, some areas of the city look a bit planned (Figure 6), but the street to street view tells a different story. The resurgence of informal commercial activities such as hawking, trading of goods, Akara and mama-put joints and shops often extended into the roads is visible. These can create traffic hold ups, and generally undermine the architectural aesthetics. $t$ is obvious that the city is challenged from both physical and socio-economic dimensions and a coordinated approach is required to manage its activities. In Kaduna city, the proliferation/ prevalence of informal commercial activities at road junctions, such as shops, suya spots, vulcanizing stands, canteens/ mini eateries, car washes, fruits, vegetable and newspaper vendor stand among many other informal activities leaves much to be desired. Examples include but are not limited to Valid Oil Junction at Sabo into Uguwan Boro, Water Intake Junction Ugwan Maigero-Narayi Road, Ungwan Mua'zu in Kaduna North area, GTB Junction at Barnawa. Closely related to this is the indiscriminate dumping of refuse by the roadside and in worse cases, on the road such as is being witnessed in some parts of Barnawa Uganda Road, Kasuwa Rd near the First Bank, Unguwar Mu'azu. Such phenomena no doubt, run counter, to both the development plan and aesthetic aspirations of the city.|
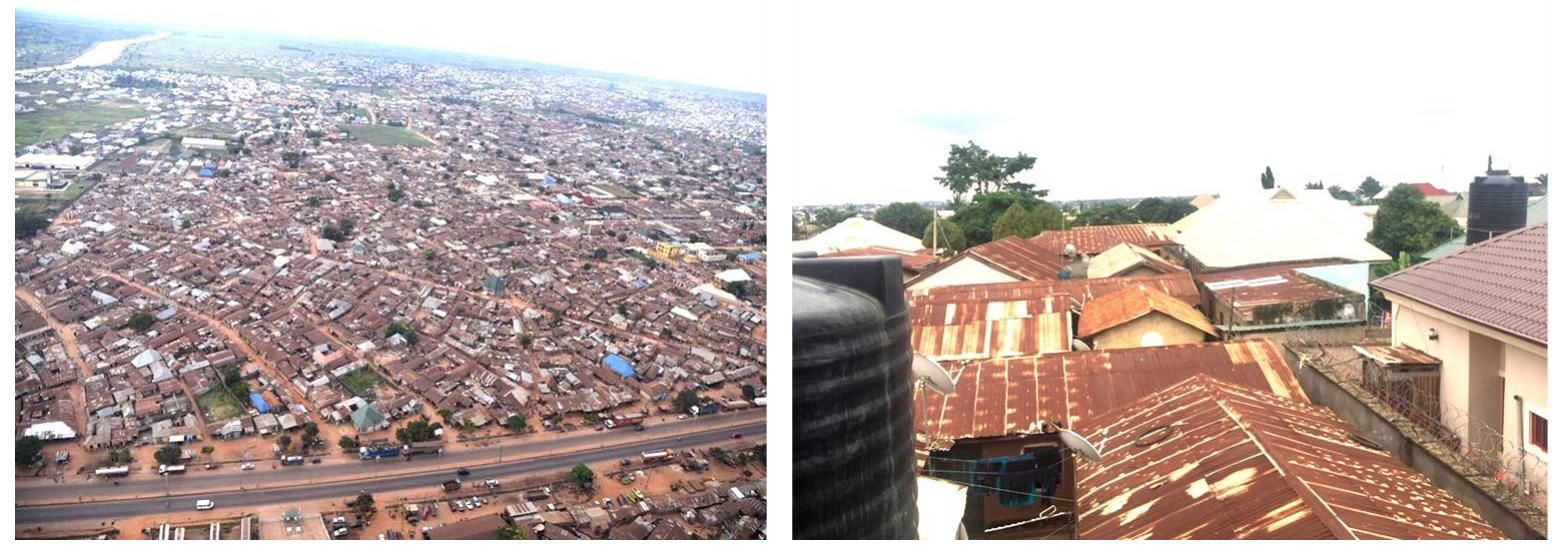
Figure 6. Drone footage of aerial and street view of Kudende area in Kaduna. (Source: Google Map, 2020)

\subsection{Environmental Quality and Waste Management System}

Environmental cleanliness is a major challenge in our cities. It is defined by indiscriminate dumping of waste (Figure 7), even on highways, pockets of stagnant water, dirty streets, air pollution occasioned by smoke from generators, faulty cars and motorcycles. Added to this is the existence of several blighted areas which require upgrading or redevelopment. There is hardly any framework put in place to upgrade or modify the architecture of buildings to appropriate levels. Where there is a concentration of the urban poor, the quality of the environment is compromised almost with impunity and the regulatory agencies seem helpless to control this (Oluwafemi et al., 2018).
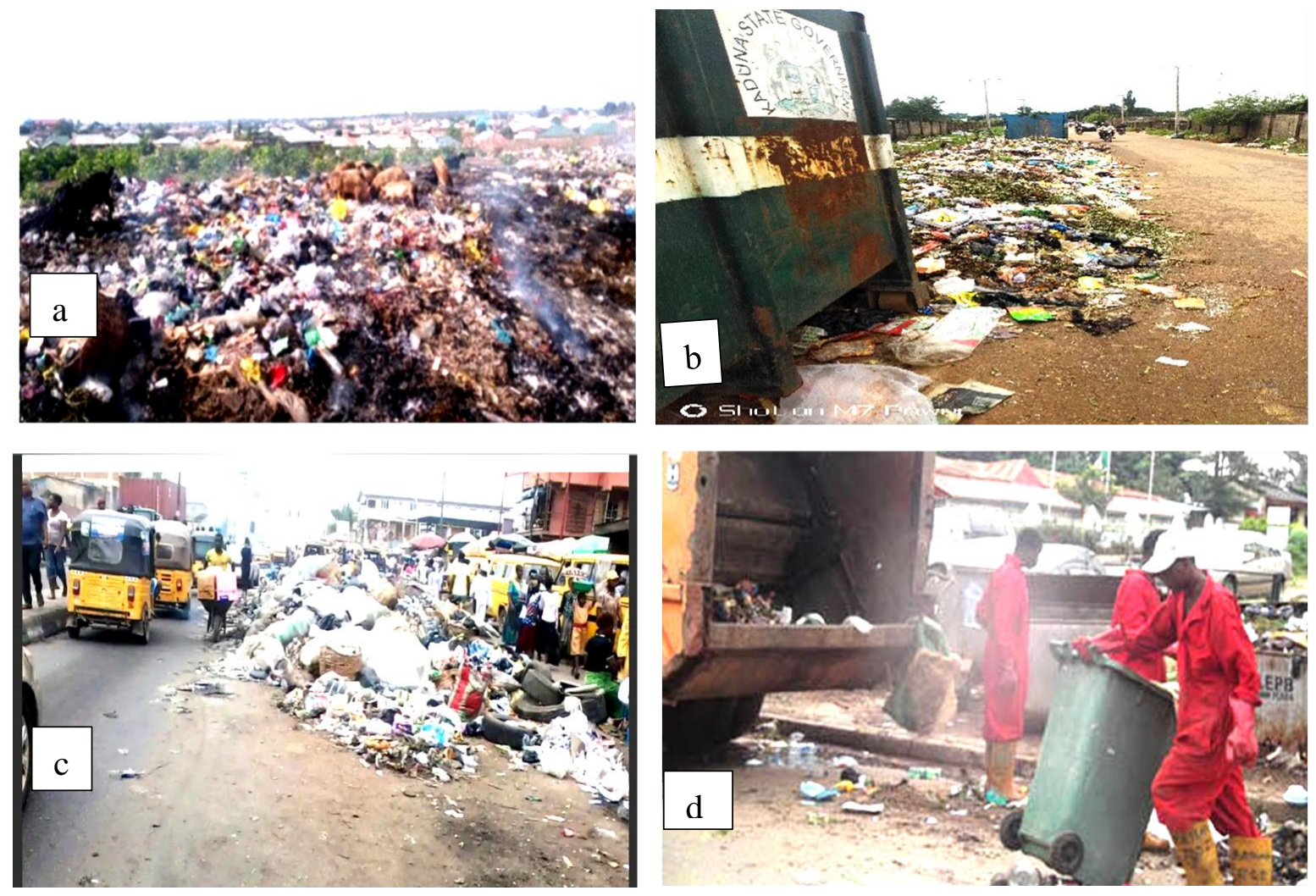

Figure 7. Indiscriminate waste disposal practices in parts of selected cities in Nigeria: (a) Kaduna South community (b) Barnawa, Kaduna $\quad$ (c) Lagos (sunnewsonline.com) (d) Kuje, Abuja (environnewsnigeria.com)

Other observable phenomenon is indiscriminate waste disposal (Figure 7a-c), erratic water supply, poor sanitation and haphazard power cable connections (Figure 5) resulting to frequent fire incidences. Many drainages are blocked with waste leading to poor sanitation. In Kaduna, waste disposal is handled by private companies under the supposed supervision of the Government in a contractual arrangement. The arrangement has not been efficient leading to abandonment of waste on the streets (Figure 6). A robust management system is needed with an independent funding and participation of citizens who are the generators of the waste. The littering of streets and road sides with waste, as seen in Figure 6 is unacceptable, as it exposes residents to health and social hazards (Makoni et al., 2004; Owusu, 2010). All wastes generated within the city should be managed with conventional techniques and the required tools of doing so. Proper disposal of waste should be a critical component of city planning. Lagos and Abuja (Figure 7d), seems to be on a better path in the 
management and disposal of waste, although much is still desired, compared to Kaduna which is lagging behind in this respect.

\subsection{Emerging Identity Fault Lines in the Cities and the Polarization Syndrome.}

A critical look at our cities, would suggest the clear manifestation of polarization syndrome along identity lines (Osaghae and Suberu, 2005). Understandably, it would seem that the unresolved issues around our national questions seem to find expression in some of our cities especially Kaduna, among other cities (Olawale, 2020). The mosaic of settlement arrangements within the urban settings is antithetical to national integration. As alluded to, such polarization syndrome is in varying degree among the cities under study, its manifestation seems to be linked to each city's immediate past experiences as it relates to stability and peace. Also important as a causal factor to polarization syndrome is the degree of integrated-ness or cosmopolitan outlook of the city. Abuja and Lagos seem to present a relatively more integrated outlook nationally compared to Kaduna. Although the Federal Capital Statuses that both Lagos and Abuja have attained, provide an intervening variable to this logic. Conversely, Kaduna has had to endure some features of restiveness in its immediate past (Wapwera and Gajere, 2017). Recent happenings in Kaduna still point to pockets of instability owing to relapse to violence between groups leading to loss of lives and property.

Consequently, riots in Kaduna have no doubt altered the pattern and urban setting of the city stimulating the rapid growth of such areas as Gonin Gora, Kwaro-Badarawa, Hayin Namani, Ungwan Dosa, Rafin Guza Ungwan Romi, Ungwan Boro and the entire swath of Sabo area (Wapwera and Gajere, 2017). Others include Jan Ruwa and Kamazo axis up to the Refinery Junction, Ungwan Kaji, Mando, Rigasa Kudandan, and Industrial areas. Nonetheless, some painstaking effort at peacebuilding by both the state and Federal government has attempted to put those bitter pasts behind even if the healing process still ongoing (Olawale, 2020; Ozo, 2009). Sadly, the healing process got into a relapse following the 2011 post-election violence that once again occasioned further polarization and tended to tinker with or reverse the confidence-building drive between groups in the city and the state at large.

\section{Theoretical Framework}

The work lends itself to three classical and two contemporary theories which for the purpose of categorization in our discourse, may be referred to, as classical and contemporary/modern theories. These are the central place theory, the concentric core model, and the sector or wedge model propounded by Christaller (1933, 1966), Burgess (1925) or Hoyt (1939) respectively. The two modern models are the multi-nucliec model and the polycentric urban models both of which advocates the creation or existence of two or more hubs of convergence or multiple Central Business Districts (CBD) in a bid to decongest or decentralize the core of the city. Three timeless principles from Christaller's work are worthy of note: Market, Transportation Network and Administration all of which constitute the predetermining drivers of the central place or the hub in terms of services to surrounding areas. They form the crux of the Christaller's central place theory. The major weaknesses in Christaller's (1966) postulation however were the superflux assumptions of an isotropic plane without any natural barriers. It also includes the even distribution of population across the city space, even distribution of resources, similar purchasing power of consumers and equal transportation cost in all directions. Such does not exist in reality, as it falls short of addressing the issues at stake in the cities under study. The concept of the CBD however provides some direction in appreciating the underlying determinant of cities in classical and contemporary times. This was further retained in the concentric core of 
Burgess (1925), and the sector or wedge model of Hoyt (1939), both of which retained the core idea of the CBD as acknowledged by Chrystaller (1966).

The principle of centrality is almost universally valid while the ideas of sector or concentric core and the corresponding expansions that radiates from them lack the element of universality. Particularly when we consider drivers such as topographies, history, land tenure system, land availability, culture, governmental actions and policies, including infrastructural adequacy etc. Taking the study cities (Kaduna, Lagos and Abuja) as references, settlement growth followed traditional patterns in the early years and later the colonial 'grid pattern' and Islamic patterns in the North. It did not really follow those forms propounded by Christaller (1966), Burgess (1925) or Hoyt (1939) as the cases may be. This was before 1991 when the FCT was transferred from Lagos to Abuja. It is worthy of note however, that although these models lack universal applicability, the study found some relevance in their core principles, processes and ideas. Some of which find expression in the outlook of the three cities under study. Such processes as invasion and succession process (where other land users are overtaken by others that were 'stronger') in land use, the idea of the CBD which is a common thread that runs through the three theories and indeed the principle of market, transportation network and administrative functions of the city remains a constant. This is very applicable in the study area where land uses are constantly experiencing daily conversions (especially where rural land use is overtaken by new urban developments). This is a frequent occurrence in the Abuja FCT and Lagos, just as market and transportation networks are determinants in urban patterns and outlooks.

\section{Materials and Methods}

The study relied on literature review, pictorial and graphic data accessed via landsat imageries, drone footages and aerial photographs and participant observations during field surveys of existing situation. These were complimented by existing base maps, development plans/master plans of the study areas, review reports of agencies saddled with development control and their associated instruments that are in use by the various agencies. Also, a key informant interview (KII) of some selected professionals/stakeholders to urban planning and development who have technical disposition and experience on the subject matter with respect to the cities under investigation, was conducted in order to corroborate findings from the surveys.

\subsection{Review of Control Instruments}

The main instruments for monitoring and control of urban development in Nigeria have their roots in the 1992 Town and Country Planning Law and are domiciled with various agencies as follows;

\subsubsection{Kaduna}

Until 2015 when the law establishing the Kaduna State Urban Planning and Development Agency (KASUPDA) was established, it is the Nigerian Urban and Regional Planning Law no 88 of 1992 that recommended the basic instrument for monitoring urban development. This law describes the responsibilities of Federal and State Governments in planning. It provides for the establishment of a Commission which is elaborate and encourages representation of various sectors such as Works, 
Environment, Commerce, Utilities and Communication. This underscores the comprehensive nature of urban planning. However, its functions are largely policy making. The implementation organ i.e. The Board, is similar to the Commission in composition but functions at the state level. This is the pattern adopted in the KASUPDA law which covers a wide range of areas such as the powers of the agency, the composition of the Board which includes professionals in the built environment, and Justice. It also includes experts from Transport as well as the Local Government and Ministry of Lands.

The Board operates through a development control unit which is often operated without the full complement of a wide range of professionals and relevant stakeholders. Under the KASUPDA law, the agency formulates state policies for urban and regional planning in conjunction with the Ministry of Lands, Surveys and Country Planning. It is expected to implement state policies for urban and regional planning, and physical development including other physical development plans and schemes while ensuring functional distribution of major roads, location of industrial, commercial, residential, and administrative areas as well as other facilities. The scheduled duties give preponderance to physical planning schemes although it is anticipated that input from other ministries will cater for other aspects of planning. For example, it is stated that "the development control unit shall be a multidisciplinary department charged with the responsibility for matters relating to the control of physical development and implementation of all physical development plans". It emphasizes the submission of a site analysis report and environmental impact analysis (EIA) prepared by the relevant professionals (Atitaye 2017). Figure 8 shows the aerial view of a major road in Kaduna metropolis that depicts the effect of proper space planning and enforcement.

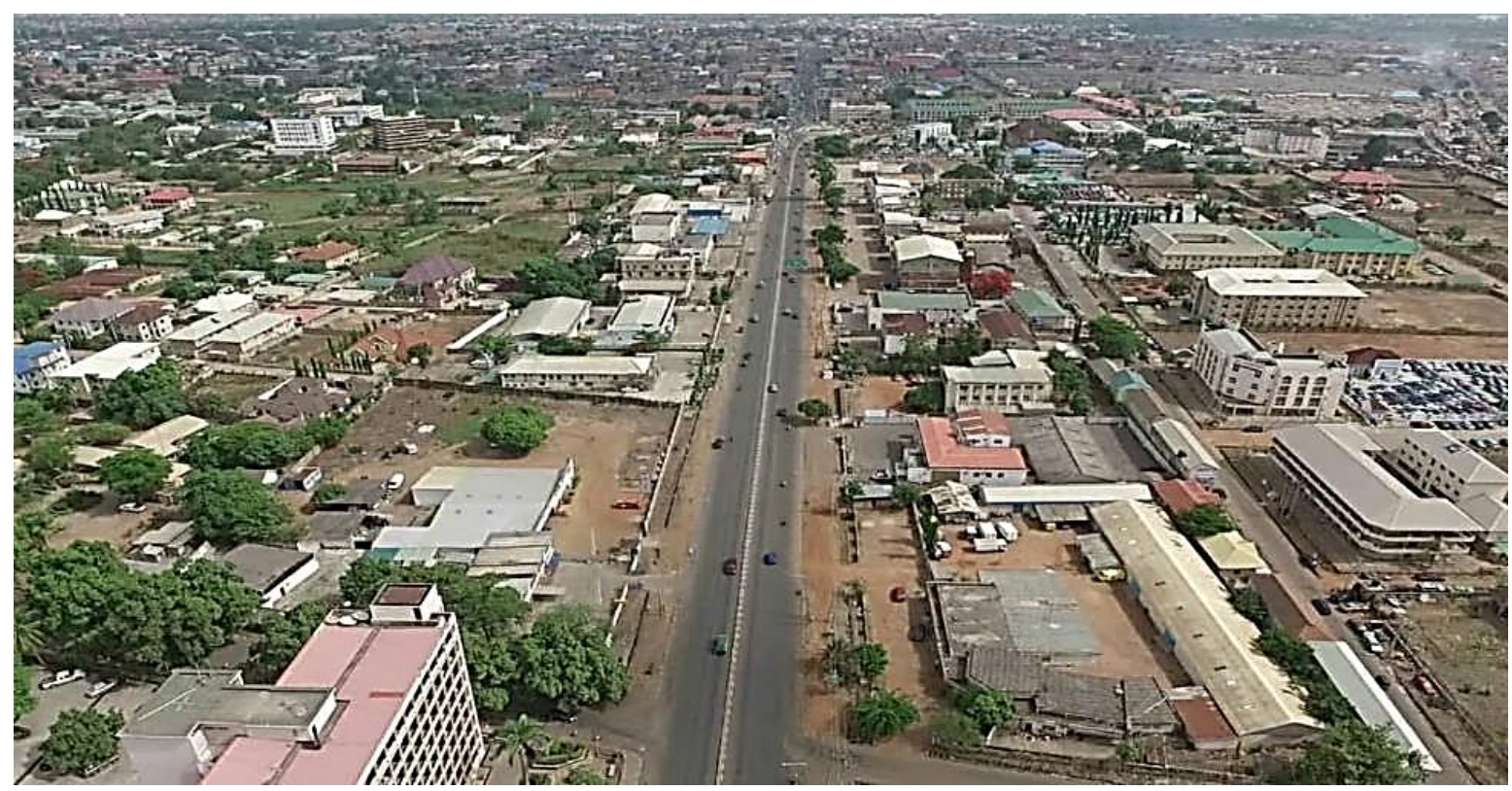

Figure 8. A face of space management and planning in Kaduna. (Source: Researchers field photograph)

The monitoring and control team of the development control unit is mainly made up of junior staff members supervised by a Senior Planner. The professional staff operates from the office and depends 
on reports from the junior technical staff who are the field workers. The law is implemented by staff of the agency who are civil servants and are bound by civil service regulations. It is noteworthy to state that there is not yet any approved development control manual to spell out details of implementation such as dimensions, levels, volume of waste and drainage systems. This has left control agents exercising discretion in some cases and has rendered their work ineffective. Recently "Event Centers" have taken over the urban space leaving heavy traffic congestion at weekends; worst still is the phenomenon of commercial tricycles known as "keke NAPEP" which is threatening to be a nuisance. Apart from interrupting traffic flow, the "keke" has proven to be a risky commodity with high rates of accidents. Recently, the state government established a Traffic and Environmental Control Agency known as the Kaduna State Traffic and Environmental Law Enforcement Agency (KASTELEA) to monitor traffic issues. This is expected to reduce the burden on KASUPDA and make for good micro-management. Meanwhile, another agency, the Kaduna Environmental Protection Agency (KEPA) is responsible for managing solid waste and control of the environment. In addition to these agencies, there is the recent creation of the Kaduna Geographic Information System (KADGIS). It is an agency dedicated to the mapping, management and allocation of land resources, their uses and property management in general. They have enhanced spatial precision to planning and development control. The decentralization of development control functions vested in Agencies is seen as a good development. However, as there should be a coordinating body to harmonize the activities of all agencies, KASUPDA by its law, is better placed to serve this purpose if strengthened and its planning and control framework reorganized.

\subsubsection{Abuja}

Qurix (2017) noted that Abuja has a comprehensive development control manual which was published in 2007. It covers open spaces, green areas, crime and change of land use. Similarly, it also addresses housing (supply and character) as well as commercial traffic and utilities. The manual articulates concepts as well as standards and procedures. It details out design requirements for housing, green areas, residential and institutional as well as commercial buildings. Over the years, the use of the manual by the development control unit has suffered challenges ranging from active non-cooperation by developers through outright contraventions of land use. The challenges also include illegal or unapproved development, manipulation of procedure through inducement of officials or through high-level connections.

The manual provides a good basis for urban governance as it articulates policy in practically all areas covered. It is however concentrated mostly on regulations pertaining to design and physical development. Nevertheless, extending detail regulations to other aspects such as green or open space, solid waste and utilities would add value to the manuals. The management of green spaces, event centers, night clubs and shopping malls should be incorporated into the manual as a new reality. Similarly, invasion or succession of land use should be adequately anticipated in the manual. The role of Abuja Metropolitan Development Agency should be strengthened. The Federal Capital 
Development Authority (FCDA) which is responsible for urban development depends on the budget of the Federal Capital Territory for funding and this is a major challenge. There is need to provide an independent budgeting/funding system for the FCDA in order to make it more effective to deliver its set objectives. The development control unit that implements the manual is an arm of the Abuja Metropolitan Development Agency unit which is the governing structure that manages issues related to development of the Federal Capital Territory. Its funding is however not independent of the Federal Capital budgetary provision.

Some of the issues arising in Abuja include heavy traffic congestions in the morning and other peak periods at the entry and exit ways into the city. Road construction works are a continuous exercise for the last 30 years. This makes movement stressful. A careful forecast of traffic before design could help reduce this. The revised development control manual is expected to have addressed "effects of new lifestyles, tastes and other realities" such as the growing influence of recreation in the city's socio-economic landscape. The rising pace of "event centers" is also noticeable in the Federal Capital. This has forced compromise of green areas in some cases. The menace of this rising phenomenon and its implications on city life and traffic is yet to be evaluated and articulated in regulatory and enforcement policies. The phenomenon is more pronounced in the epicenters such as Kubwa and Karu. "Night life" outlets are springing up fast with attendant consequences such as providing a conducive environment for criminals. The manual has detailed out dimensions, sizes and in particularly all types of buildings. However, it is to be observed, looking closely at planning densities and number of families, that there appears to be some inadequacies. For instance, the allowance of 6-8 families on a plot of $750 \mathrm{~m}^{2}$ in a block of flats for high density plots appears inadequate as it leaves each family to just about $100 \mathrm{~m}^{2}$ (Qurix 2017). Similarly, for medium density plots, even at 6 families for $150 \mathrm{~m}^{2}$ per family, it is still inadequate. Plots that are up to $2500 \mathrm{~m}^{2}$ where one is allowed to build Gazebos, gate houses, generator houses and proper landscaping are likely to be located outside the city center, or if found within, would be very expensive. In Abuja, such a plot could cost up to Two Hundred Million Naira ( $\$ 200 \mathrm{~m}$ ). There is need to lower the number of families expected on the high and medium densities plots in order to reduce consequences of over stretched utilities and traffic congestion. Issues concerning affordability for the majority of peasant residents has been a source of concern and has been seen as a failure of planning and implementation. At Gishiri Village by Aso Hill Abuja, a housing estate as seen in (Figure 9a) was meant to resettle indigenous communities, but the residents refused to move in as they could not afford the cost of such houses neither were they willing to abandon the peasant simple lifestyles in their abode with a more tenable sense of community (see bottom section of Figure 9b). 

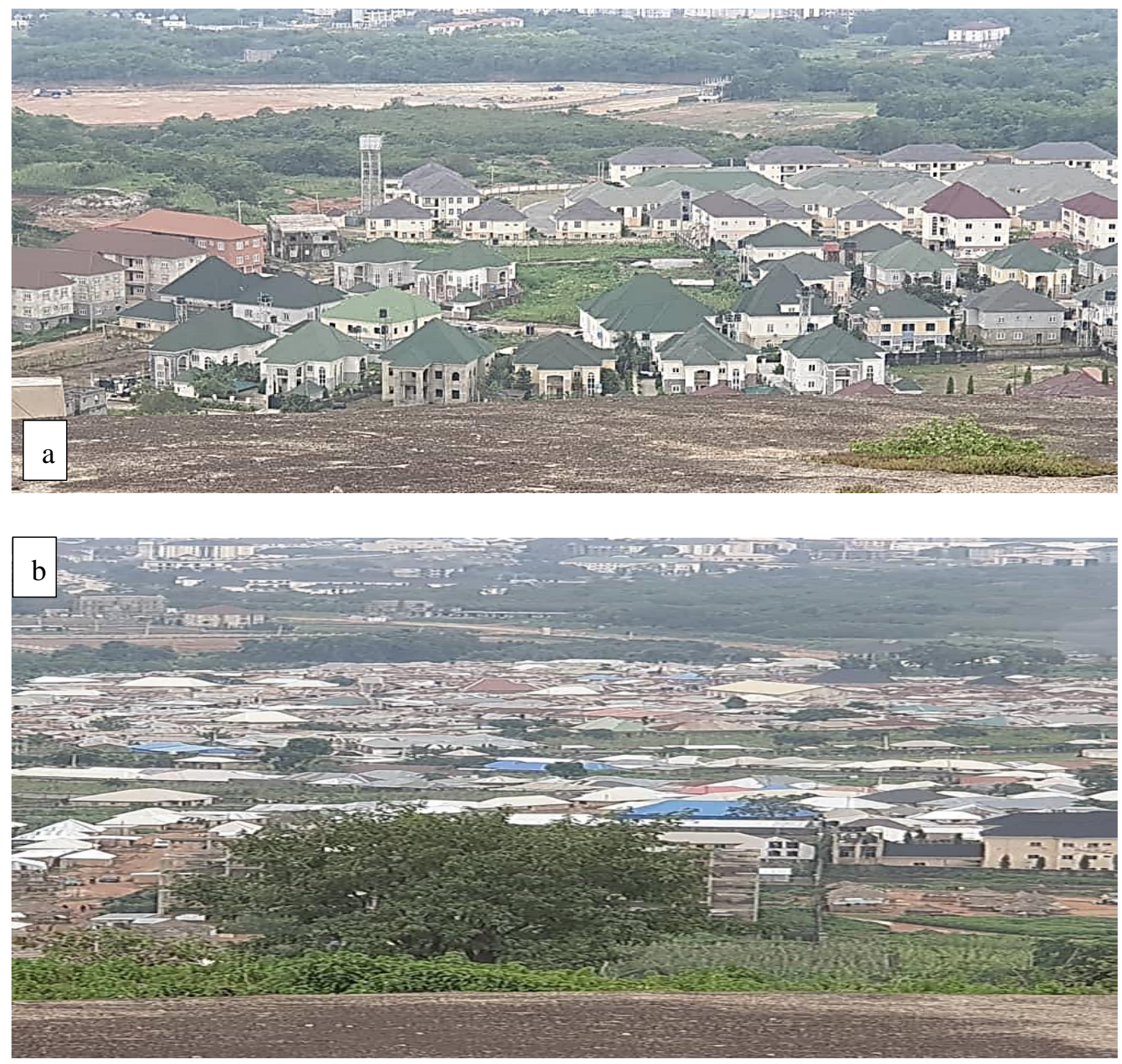

Figure 9. Gishiri housing estate, Abuja. (a) Planned housing system (b) continuing peasant housing by locals (bottom section of photograph). (Source: Researchers field photograph)

\subsubsection{Lagos}

The Lagos Executive Development Board was in charge of drawing planning schemes. It successfully drew the scheme for the clearance and re-development of Marina which was then a slum. This paved the way for widening of access roads, allocation of planning densities and improvement of traffic congestion especially between 1959 and 1961 as well as improvement of architectural designs and plans. The work of the Board saw the completion of arterial roads like Nnamdi Azikiwe and Broad Street. By 1972, more commercial buildings were already built but a functional sewage disposal system was yet to be attained. The Board had earlier identified this problem in 1957. As the population of Marina increased in the 70s, it was necessary to address security concerns arising from high population in the daytime and absence of people at night (Marina being a commercial area). The Executive Board was therefore set to facilitate holistic development. The main document used for planning regulation by the Board was the Lagos Town Planning Ordinance of 1928 which was 
reviewed in 1958. The composition of the Board in 1958 suggested that it was positioned to address engineering, transportation, political, commercial and social concerns. The functions of the Board were subsequently decentralized. In 1972, the Lagos State Development and Property Corporation (LSDPC) was established as a result of the amalgamation of the three existing agencies i.e. the Lagos Executive Development Board (LEDB), Ikeja Area Planning Authority (IAPA) and Epe Town Planning Authority (ETPA) (Heinrich, 2016).

The LSPDC continued to provide basic infrastructure as well as maintain them. It provided housing and managed same. It was given powers to carry out any activities that were necessary for its function. The Lagos State Development and Property Corporation took over planning responsibilities. It was comprised of an Architect, Engineer, and Planners with no full-time financial expert (Qurix, 1989). One interesting regulation that the Corporation adopted was the insistence on the incorporation of parking space within commercial buildings in Lagos. This, proved very useful, but the traffic situation worsened in the 70s and 80s especially at the Lagos Island as a result of rising commercial and socio-economic activities. It appears as if Lagos enjoyed prosperity in the last few years, which approximately coincides with the re-establishment of democratic rule in Nigeria. Congested areas have cleared with both soft and hard landscaping as development controls became stricter and external investment grew (Ogundele et al., 2011; Ezema et al., 2016; Olufemi and Ambrose, 2018).

In 2010, the Lagos State Urban and Regional Planning and Development Law (LURPL) was adopted, to provide for urban development, urban regeneration, building control and for connected purposes. Under the law, several institutions connected to urban development are to play specific roles. These are the Lagos State Physical Planning Permit Authority, Lagos State Building Control Agency and Lagos State Urban Renewal Agency. These are to implement the policies of the Ministry of Physical Planning and Urban Development (Heinrich, 2016). Among others, the role of the ministry includes: "responsibility for physical planning, urban development, urban regeneration building control policies. It is responsible for initiation, formulation of policies, and coordination of programmes and renewal of all aspects of physical planning, urban development, urban regeneration and building control in the state". The LURPL is quite comprehensive and tends to provide an important model for urban management. It covers policy initiation, implementation and redevelopment as well as provide an effective management role of the coordinating Ministry of Physical Planning and Urban Development. With a strong political will, it has a high potential of ensuring well balanced urban development. This law (LURPL), though recently amended (Lamudi, 2014), still has all the main sections untouched.

\subsection{Interviews}

In an interview with a resident of Kaduna, Mr Bala, who is a professional architect and has lived in Kaduna for over 30 years bore his mind thus: 


\begin{abstract}
"Kaduna can be described as having witnessed a change in land use, in many areas; specifically, there has been redevelopment/conversion of existing land use into another such as retrofitting of residential areas for commercial uses and residential buildings for institutional or recreational uses. On the other hand, there has been massive infrastructural expansion especially roads, attempt at renewal of decayed infrastructure, such as roads and markets among other considerations. However, there is a lot to be done on the socio-cultural front. For example, community-based service assessment and provision is virtually absent. Public Private Partnership (PPP) schemes often neglect original users such as in market development. Lack proper attention to slumps and poor maintenance culture are among the major setbacks of urban development in Kaduna".
\end{abstract}

He further identified the fact that lack of a formidable development control enforcement team, and an unreliable land allocation system with attendant delay in processing of Certificate of Occupancy (C-of-O), have contributed negatively to urban development in Kaduna. Similarly, a professional Planner, Mr Atiyaye who has lived in Abuja for over 25 years, observed that changes in Abuja land use include the conversion of residential and recreational areas to commercial and mixed uses. He further pointed out that there are cases of encroachment into road junctions and right of ways, citing Wuse, Garki II and Gwarinpa as areas affected. However, he opined that there has been remarkable gentrification in terms of replacement of dwarf and derelict structures with taller ones and densification of new districts as a result of modification of development control guidelines. He identified the proliferation of informal settlements within and around the city. He cited the proliferation of "mass houses" instead of "mass housing" where the houses built are inaccessible to the target population due to cost. In some cases, the houses are abandoned due to poor infrastructure. Abandonment of mass housing schemes is a fairly common phenomenon in our cities. In Kaduna for example, the Millennium housing scheme as well as the Takau Housing Scheme in Kafanchan have un-serviced infrastructures, and hence have been abandoned.

\title{
5. Findings
}

From the review of literature, and surveys, the following could be deduced:

\subsection{Population}

Urban population is made up of rich and poor, but perhaps a higher proportion of poor people. In Nigeria, the proportion of poor people was estimated to be $69 \%$ in 2010 according to the National Bureau of Statistics (NBS, 2012). In the urban areas, it may be between 25 and 35\%. Population is usually used to rank cities and growth rate. However, it is obvious that in many Nigerian cities as in African cities, the urban structure is not built for productive purpose but for administrative purpose and extraction of economic surplus. Thus, there lies weak economic base, unconducive for optimal growth. Hence, categorizing the cities using only population as an index therefore may not serve a 
useful purpose for planning as population may indicate how urbanized a city is, but may not point to its social and economic development indices. The National Bureau of Statistics (NBS) has established harmonized living standards (HLS) which has measured Demography, Health, Fertility, Education and Skills. Poverty profiles have been established between 1980-2010 and are expected to guide social and economic programmes (NBS, 2012). These are however hardly integrated into comprehensive planning. It may be necessary to aggregate other parameters together with population in order to evolve a Development Index for the cities.

\subsection{The side-by-side Juxta-positioning of planned and unplanned communities}

As revealed by the study, the existence of both planned and unplanned sections in the same area is a common phenomenon in Lagos, Kaduna and Abuja. Clearly, there is an economic reality to this. First, the urban slum areas benefit from the provision of ample infrastructure such as good road network, steady supply of electricity made available on the account of the planned areas but which extends to them as well. There is mutually beneficial relationship between the two residence in terms of services such as relatively cheap food products, readily available semi-skilled labor such as artisan services, markets and cheap casual labor. These are ironically located in the unplanned residence which enjoys the patronage from residents of the planned community. This points to the mutually beneficial relationship between residents of both groups .be it from the class or cultural divide. It also suggests that development control and the machinery of state ought to be more pro-poor as many can hardly afford the cost of housing being provided by modern estate providers. While Figures 10 to 13 depicts well planned areas, Figure 14 shows a case of this side-by-side location of planned and unplanned communities. It is an evidence of poor planning and a lack of pro-poor planning initiatives. If the cities were well planned, satellite communities could be created that are properly linked to high-brow areas with good roads while affordable housing is provided in the satellite communities as was envisaged and implemented in the Federal Capital Territory. Examples are Kubwa and Lugbe satellite towns in the FCT. 


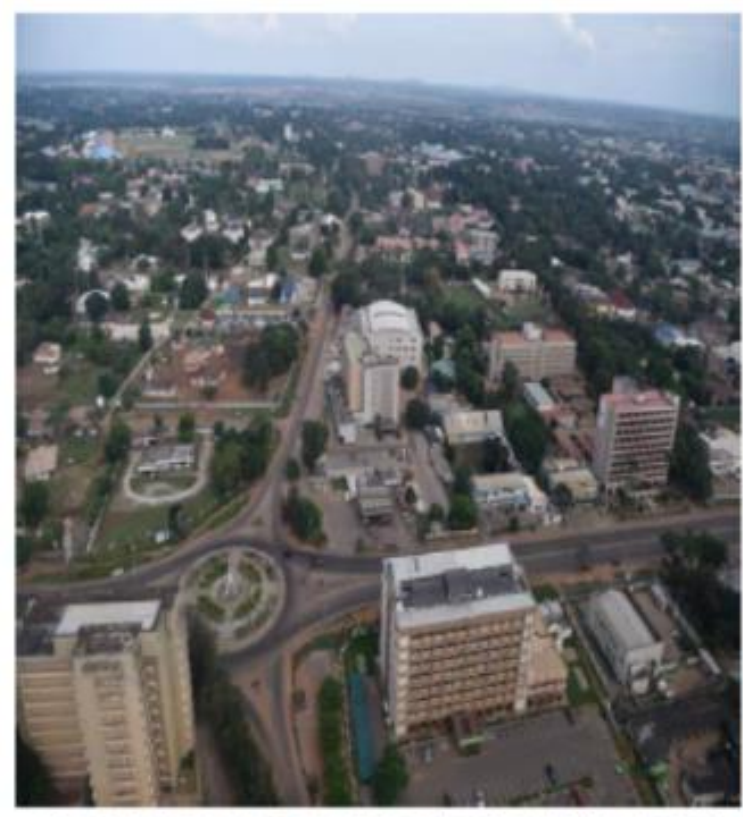

Figure 10. NEPA Roundabout along Ahmodu Bello Way Central Areo Kaduna. (Source: Researcher's field Aerial Photo)

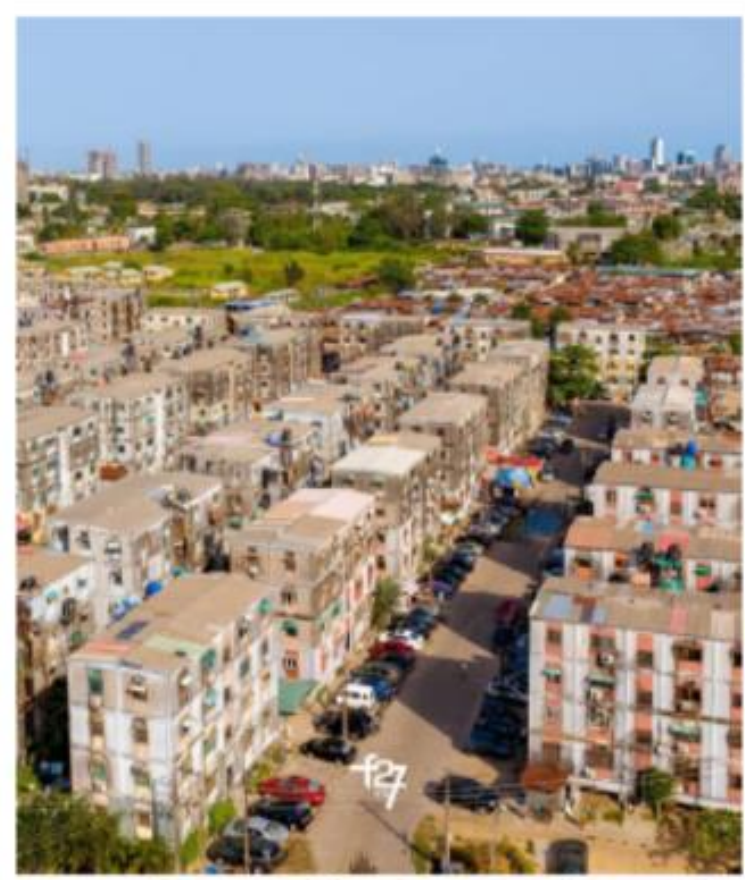

Figure 12. Planned residential areo in Hoyi, Lagos. (Source: Google image 2020)

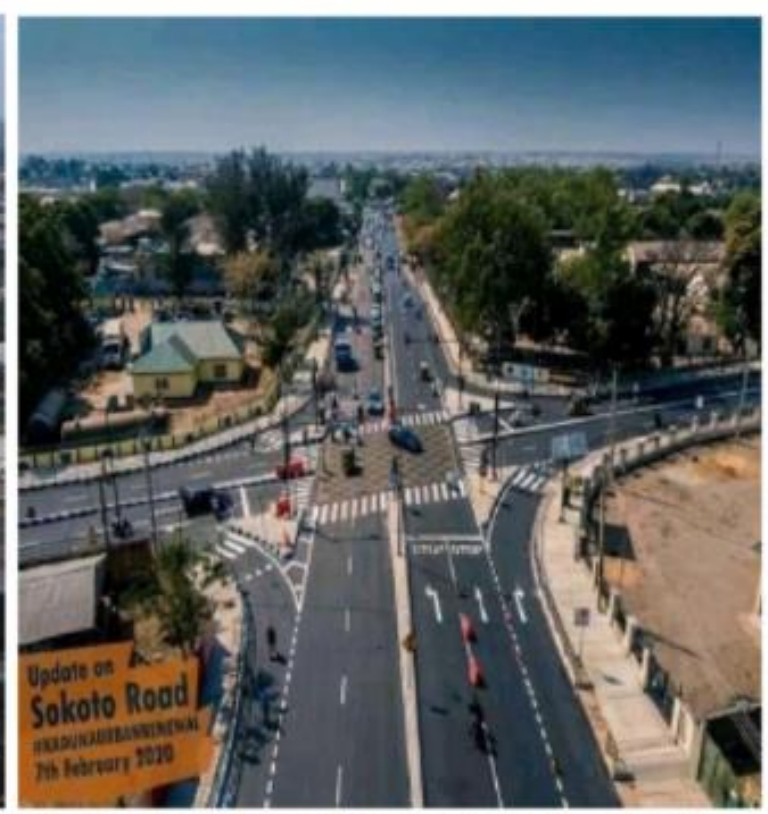

Figure 11. Solioto Road, Kaduna. (Source: Google Image 2020)

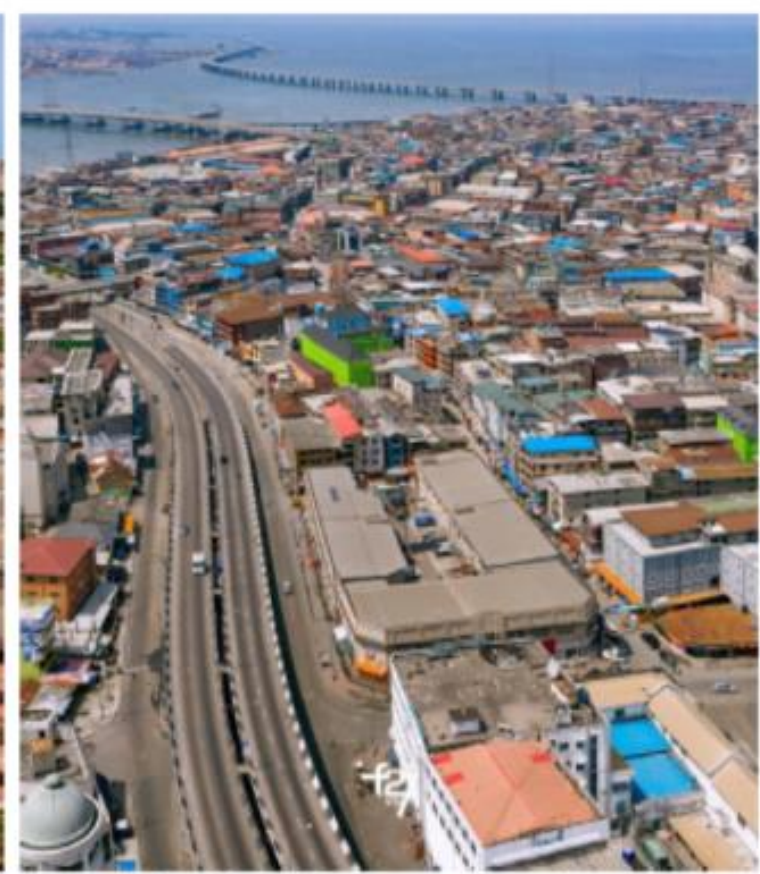

Figure 13. Planned but crowded commercial area in Aponbong, Lagos. (Source: Google image 2020) 


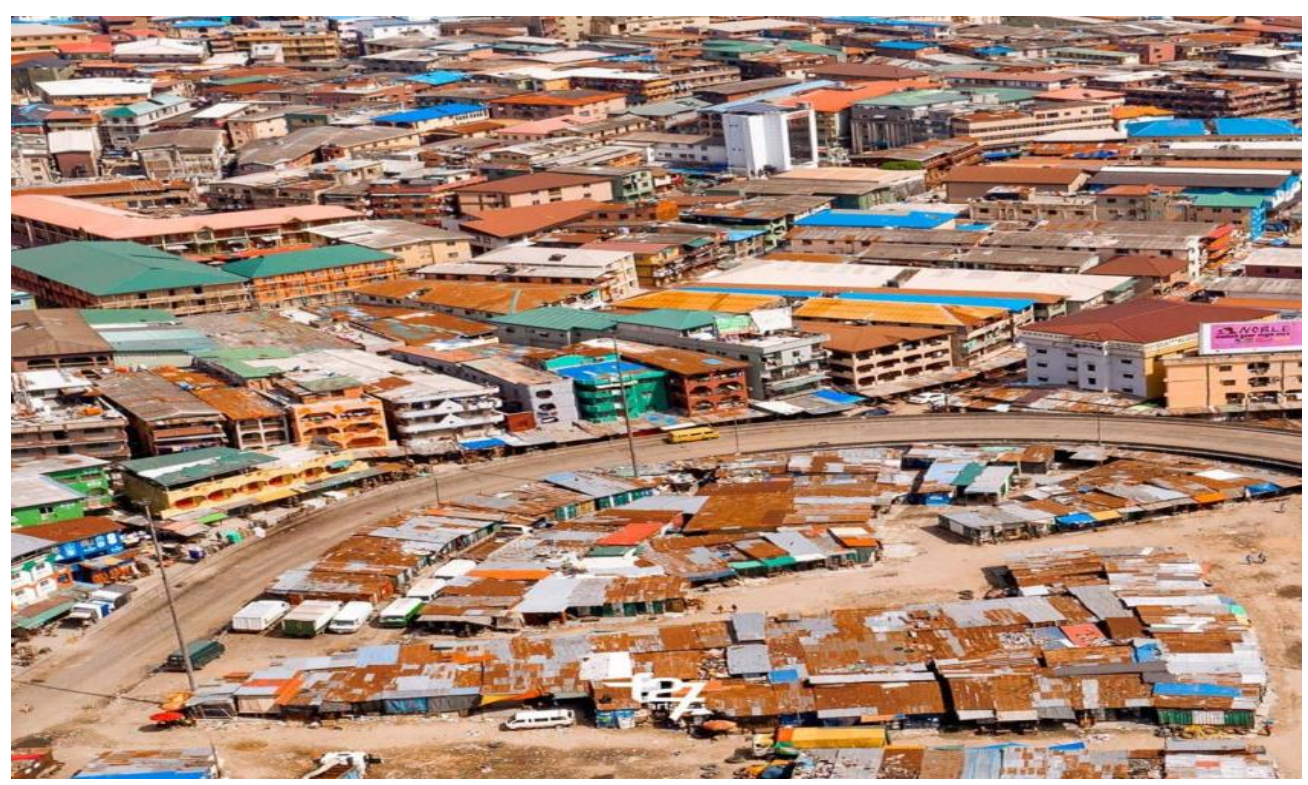

Figure 14. Juxta-position of planned and unplanned communities

\subsection{Infrastructural Deficit}

In the three cities under study, cases of infrastructural deficit were found although in varying degree depending on a number of functions for each of the cities. Abuja is understandably more favorably disposed to more ample infrastructural provision compared to Kaduna for instance. Lagos is expanding more rapidly than the infrastructure provided although a firm and visionary leadership with strict adherence to modern planning, is making a lot of difference in the commercial capital of Nigeria. On the other hand, Kaduna is witnessing a mix of a historic cosmopolitan regional capital with an attempt at modernizing the city in both aesthetics and infrastructural development. A deliberate urban renewal with a clear roadmap being provided by an existing master plan seem to hold sway in Kaduna.

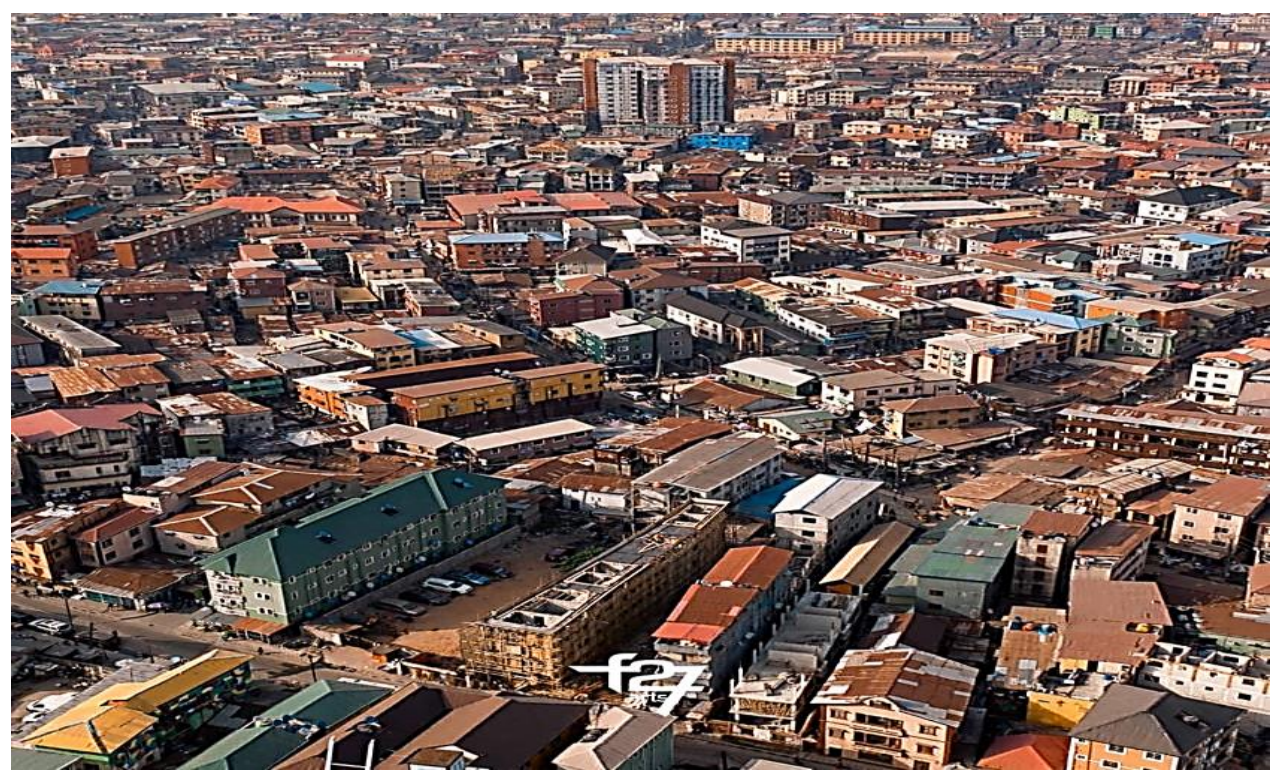

Figure 15. Footage of an area with infrastructural overstretch 
Figures 13 to 15 shows crowded areas with evidence of outstretched infrastructures. A worrisome sight for any professional planner and those of mindful of city aesthetics. Policy makers and City Officials need to ensure that such situation do not arise in future cities and deliberate effort (political and financial) should be made to reclaim the beauty and aesthetics of existing cities.

\subsection{Lopsided Urban Provision Within the Same City}

Lopsided development and contrasted infrastructural provision that seem to ignore a part of the same city, was noticed in Kaduna. Such unwholesome trend risks retarding the overall objective of city planning in addition to aiding the embers of disintegration among residents. Similar observations was made by Ozo (2009) in his study of urban transformation and conflicts in Benin City. Moreover, it makes the ranking of such cities very difficult. Unfortunately, in Kaduna city, the data and the field observation seem to point to manifest cases of politicization of city planning and one that is not only lopsided but a response to political bickering with obvious identity preference in the provision of infrastructure. This is a huge compromise on city planning as it portends to undermine the greater good and the overall objective of city planning. The consequences of this negative trend are many including the feeling of exclusion by a section of the city or state can undermine the legitimacy of leadership at every level in addition to sowing a seed of discord among the various polities in the state (Wapwera and Gajere, 2017). Sadly too, this ugly trend exacerbates the already polarized city and thus, constitutes obstacles to the needed national integration. Goningora community, located in Kaduna city is a typical example as shown in Figure 16 where there are no visible tarred roads compared to Kaduna metropolis.

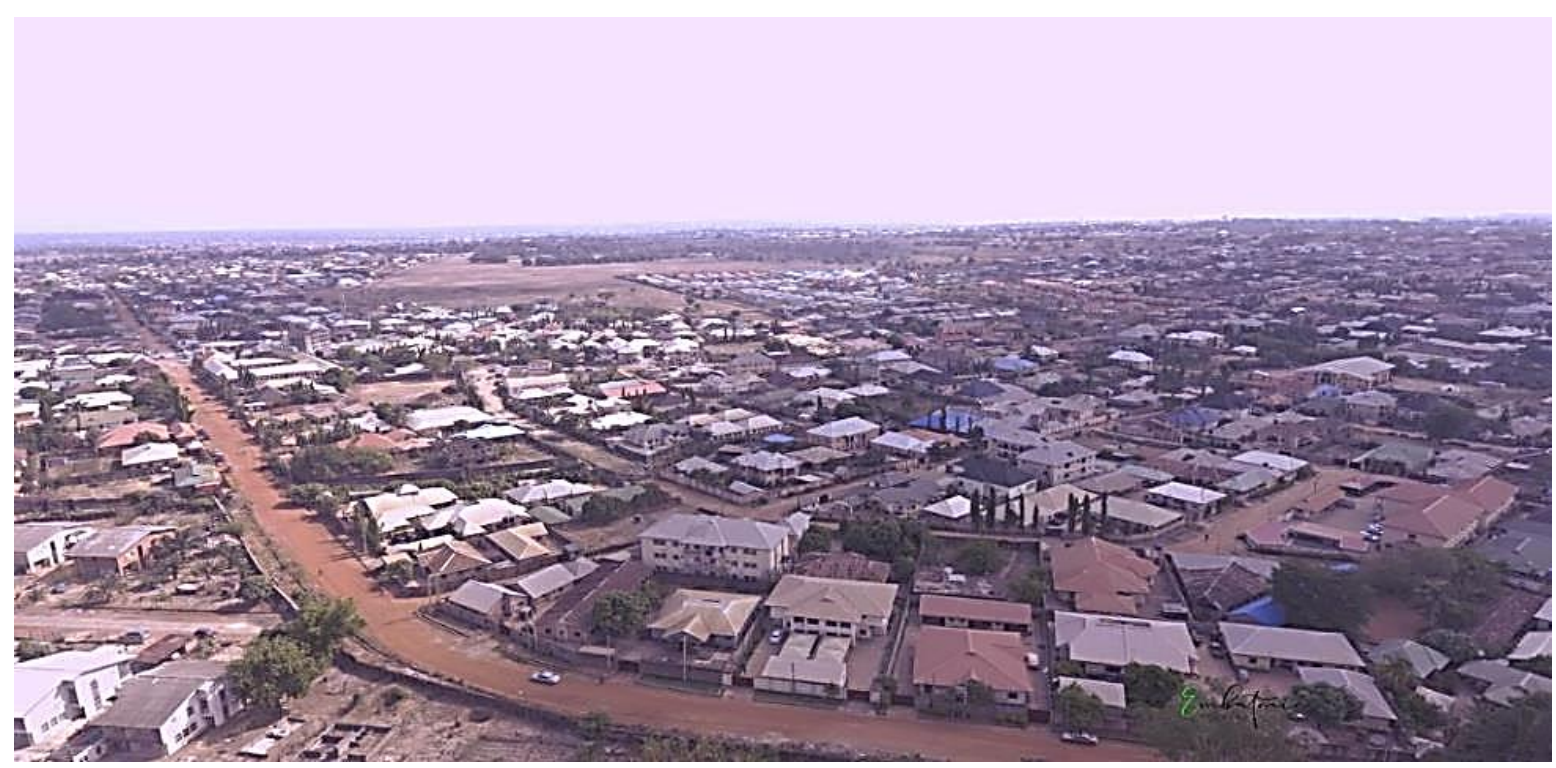

Figure 16: Goningora, Kaduna, a community that sprang out of response to 'safety' and identity polarization phenomenon owing to past violent contestation in Kaduna State. (Source: Researchers Field Photograph)

\subsection{Infrastructure Profile}

The African Development Bank Group has identified that inadequacy of infrastructure for meeting basic human needs and growth is undermining the economic performance of almost every 
city or town in Africa. Infrastructure has been shown to be the bedrock of development. The provision of roads, housing, utilities and public buildings is indispensable for the growth and development of the urban areas. Of concern to the study findings is the gap of sustainability plan in dealing with infrastructure. The study revealed that the dynamics of change are not sufficiently taken into account with respect to infrastructural provision which is consequently soon overstretched for the same reason. Adama (2018) recently pointed out some of the challenges faced in engaging in funding mega structures and projects in Lagos, Nigeria. Of note was the observation of how such projects are fractured by certain beliefs and indulgences that supports social exclusion and unabated inequalities and the lack of pro-poor considerations.

\subsection{Environmental Management}

While Lagos and Abuja seem to point to modern system of environmental sanitation and management including waste recycling, Kaduna is still lagging behind. Consequently, the practice of waste management and waste disposal still leaves much to be desired as fermented and decayed waste litters some parts of the city often at the peril of its supposed aesthetics. In Lagos, the possibility of expanding many roads is slim as any attempt to divert road traffic to allow for work would be catastrophic in view of the heavy volume of urban traffic. Housing deficit is largely responsible for the emergence of poor urban areas or slums (Qurix, 2017; Ozo, 2009). This notwithstanding, the extent to which planning has made things much better in Lagos than they would have been, cannot be overemphasized. Despite the effort made in Lagos towards an efficient environmental management, there are a lot of issues that points to unsustainability, the government needs to do more as was recently reported (Onuminya and Ize, 2017). The FCT is doing all she can to avoid the pitfalls of other cities in Nigeria in ensuring strict compliance to environmental management and particular attention to municipal waste management. However, more needs to be done as there are observed littering of some streets where citizens struggle with improperly disposed waste (Kadafa, 2016). There is need for these Nigeria cities to fully embrace modern waste management practices that converts these "public liabilities" to wealth by adopting the result-driven technologies and waste to wealth philosophies (Olukanni et al., 2018; Ibrahim, 2020; Sridhar and Hammed, 2014). One observable phenomenon in the cities under study is the near absence of public conveniences. The cities appear not to be visitor-friendly. Few car parks have pay-service convenience that are unreasonably exorbitant. The few scanty public conveniences are so unkept that they cannot be visited a second time. In addition, the sight of blocked drainage systems (see Figure 7) and their absence in certain places is common with flooding of major roads and communities been a regular occurrence (Figure 17). As a nation, this poor drainage systems and the resultant flooding have huge consequences on our ability to meet the required sustainable development goals (SDGs) as recently enunciated (Echendu, 2020; Ajibade et al., 2013). Whole communities have been reported to be submerged in flood water with human fatalities. In some cases, communities have been swept away in some form 
of landslides. The media was recently awash with news of flooded communities in Lagos, Abuja and even Kaduna with fatalities and other collateral damages (Figures 18, 19, 20 \& 21).

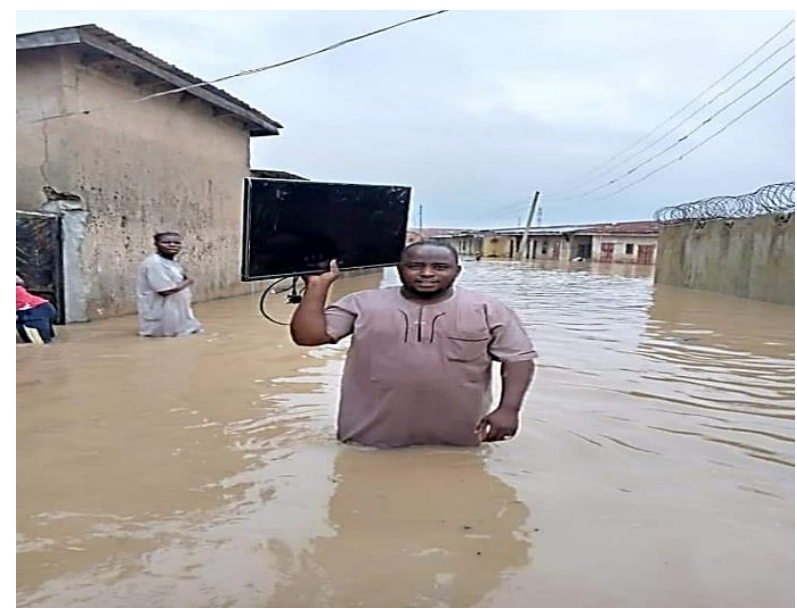

Figure 17. A Flooded residence at Kabala Costain due to poor drainage system (Source: Researcher field photograph)

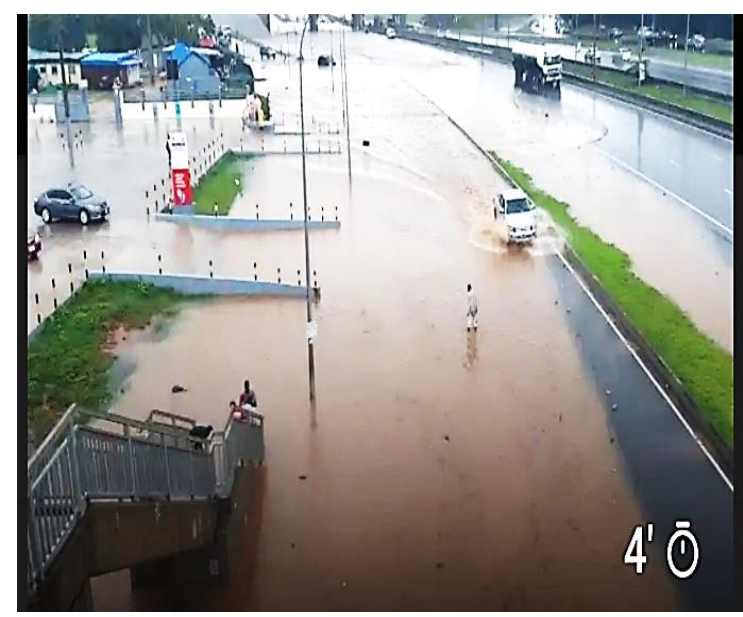

Figure 19. Flooded major road in Kubwa, Abuja (Source: Punch news 24 Sept, 2020)
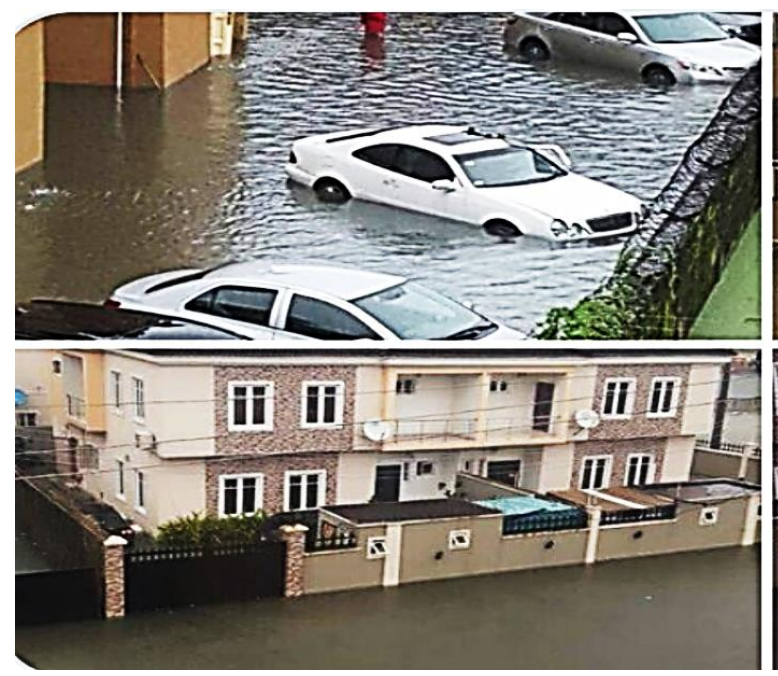

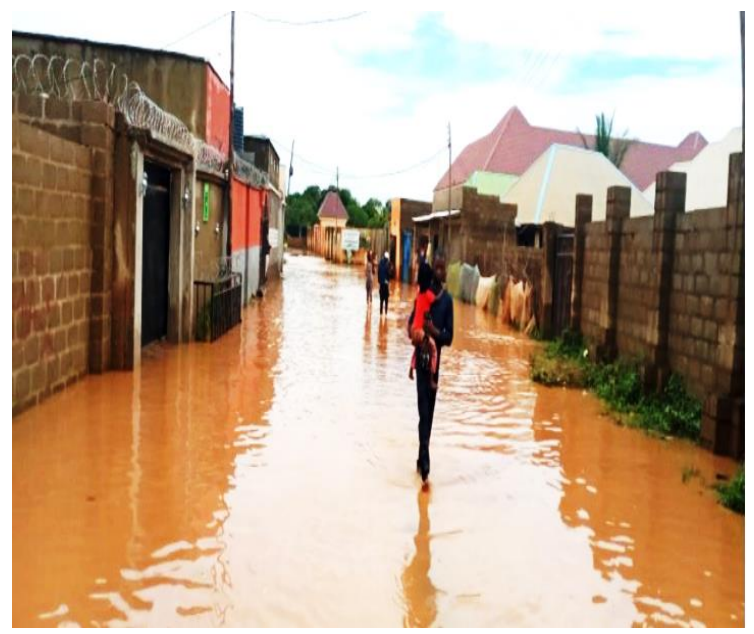

Figure 18. Flooded Kaduna community. A repeated scene (Source: Guardian newspaper of 01 Sept, 2020)

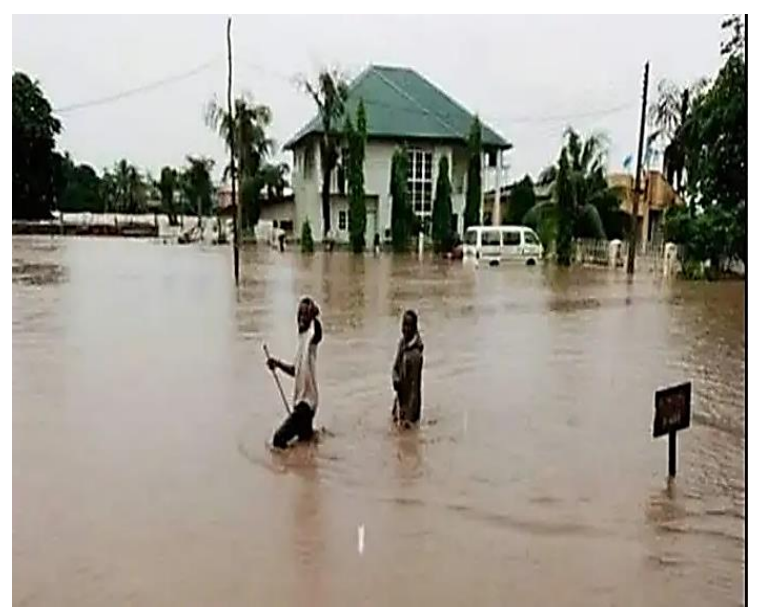

Figure 20. Flooded area in Gwagwalada, Abuja (Source: bbc.com)

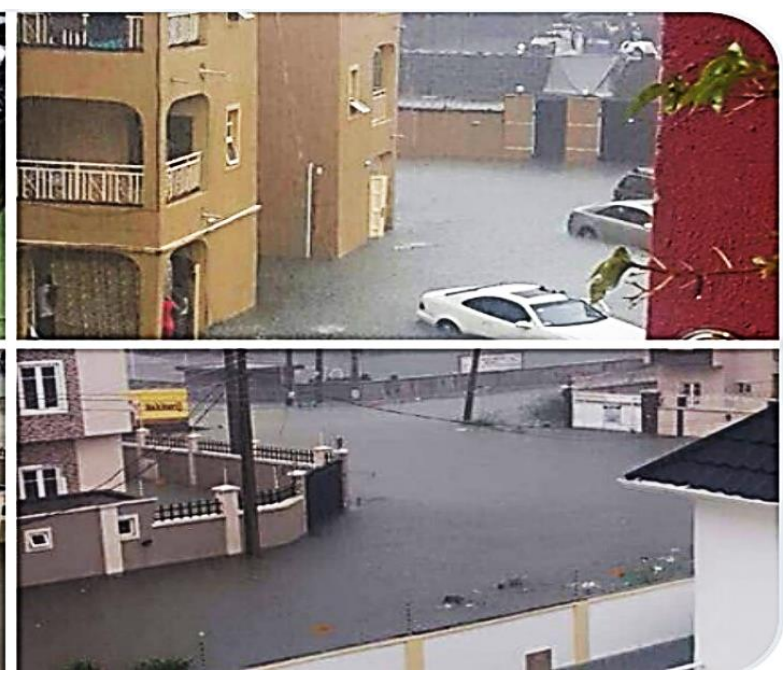


Figure 21. Flooded residential quarters in Lekki, Lagos (Source: Quartx Africa 08 July, 2017)

Kaduna City had a well-drawn out plan by the colonialist with good road layout and provision of adequate public housing. With the rise of urban population and the physical expansion of the city's territories in the last 30 years, settlements such as Rigasa, Rafingusa, Romi, Maraban Rido and GoninGora, have sprang up but with poor road infrastructure and housing (Qurix 2017). Government in the last 15 years embarked on a land parceling misadventure called "carved-out". Here, a parcel of land (often with obtrusive dimensions) is excised from an existing plot and allocated to another occupant, leading to poor quality environments, uncoordinated development (as the new occupant has no business with the original occupant) and over stretching of utilities as well as compromise of green areas. Quite clearly, GoninGora settlement in Kaduna is a community that sprang out of response to 'safety' and identity polarization phenomenon which is visible within Kaduna metropolis (Figure 16). Also, of grave concern in Kaduna is the sharp contrast in terms of road infrastructure as an important index of urban development between different parts of the same city (Figure 16). It is hard to marry the well-developed road networks in Kaduna North and the un tarred roads of say Kaduna South or Chikun LGAs.

\subsection{Traffic Management}

There is hardly any Nigerian urban area that does not suffer from traffic congestion particularly during morning rush hours when work begins and at the close of business day. The situation was common only in Lagos up to the late 1990s, forcing workers to wake up as early as 4am and return home as late as $11 \mathrm{pm}$. Under this situation, productivity is low as the worker is bothered about logistics rather than the work. Similarly, vehicles frequently breakdown along traffic as a result of poor vehicle regulatory compliance (Road worthiness). Hold ups known as "go slow" or traffic jams are regular leading to high cost of vehicle maintenance (Figure 22). There is poor adherence to traffic rules and more worrisome is the unreliable nature of traffic controls because of frequent power outages. Crime is naturally invited along the way as "Area boys" "yan sarasuka", yandaba" depending on the city, harass helpless motorist along the way. Besides, hawkers make brisk business along major traffic routes and further compound the traffic situation. Observation along major streets of Ikeja, on weekdays also reveals this scenario. Similarly, in Kaduna, North-South traffic situation between $7 \mathrm{am}$ to $10 \mathrm{am}$ and $4 \mathrm{pm}-8 \mathrm{pm}$ has remained a thing of concern. Also worthy of note in Kaduna is the recurrent phenomenon of flood within the city every year that hampers free flow of traffic particularly during peak times. It would appear that the authorities have not done enough to stem the tide of flooding often occasioned by poor drainage system in the city. 

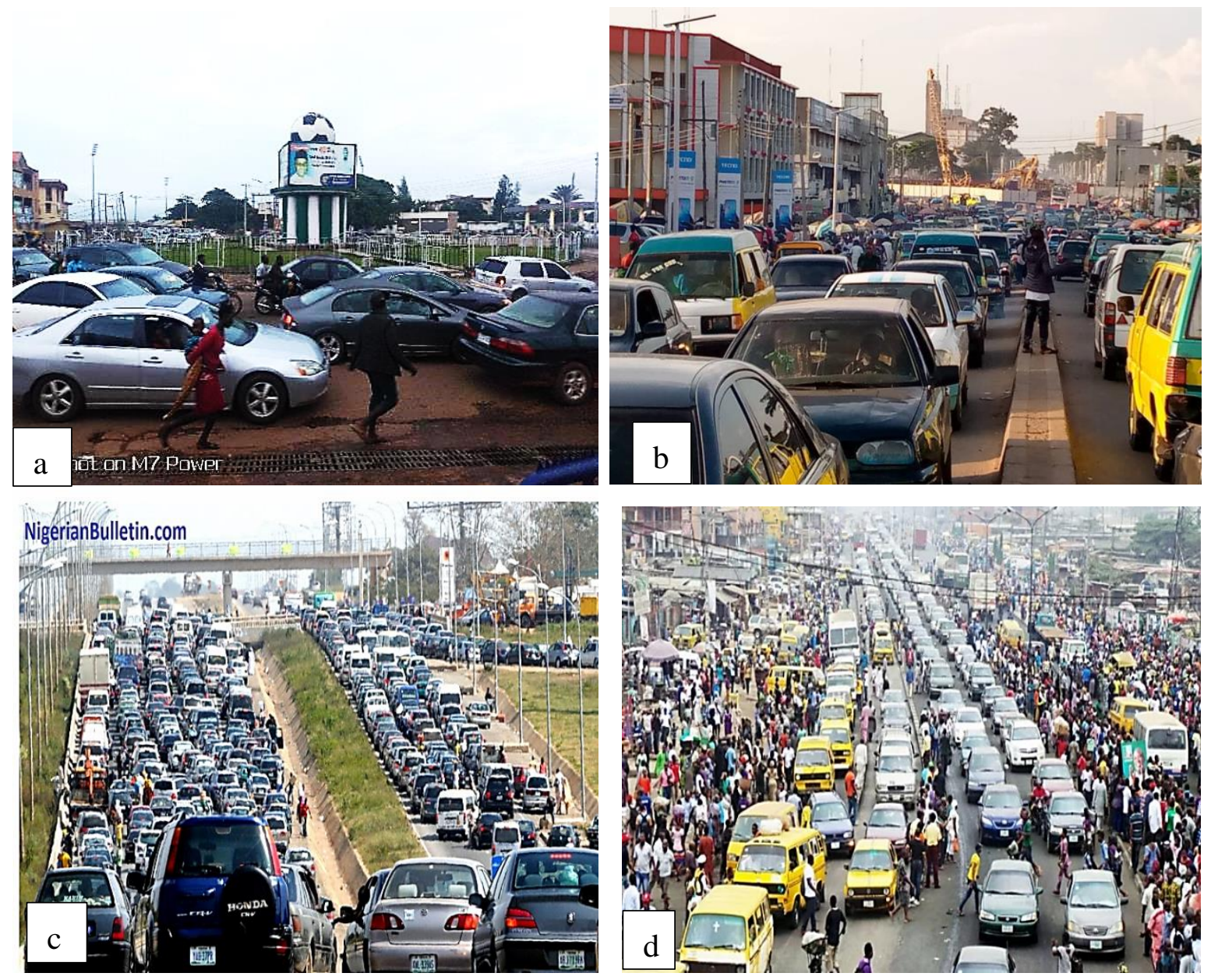

Figure 22. Photographs of traffic jams in some Nigerian Cities. (a) traffic holdup at Ahmadu Bello Stadium roundabout in Kaduna (b) Traffic hold up in Kasuwa, Kaduna. (Source: Researcher field photo) (c) Congested traffic in Kubwa, Abuja (Source: NigerianBulletin.com) (d) Congested human and vehicular traffic in Lagos (Techpoint.Africa)

Similarly, when the Carter Bridge in Lagos was built in 1962, it was thought to reduce congestion and eliminate delays hitherto created by pedestrian crossing the road through it's under passes. Subsequently the third mainland bridge was built. This served to improve the traffic situation between the mainland and Island although for a short time. In Abuja, there is currently only one access from Nyanya to Abuja and the vehicular traffic is plagued with congestion, accidents, crime and other prevalent vices. In Kaduna, two bridges served to link the north and the south until 2010 when the third bridge was constructed to open up a suburb "Dan honu" and the new Millennium City. This was borne out of the concept of creating deliberate satellite centers to attract inhabitants from the city center. This is a laudable initiative but one which has suffered a setback due to lack of appropriate infrastructure and paucity of steady fund. Perhaps the construction of the fourth bridge in 2012 was indeed a water shed moment in the development of road infrastructure in Kaduna. The road leading to the bridge serves as a major exit for travelers to Abuja and the southern part of the state and in a way frees the center of the town. However, uncontrolled commercial activities are already beclouding the road and require urgent state intervention. Pedestrian walkways are hardly 
provided for and road shoulders are unavailable. This has led to several accidents. These walkways and shoulders should be part of future road designs and construction.

\subsection{Architecture}

Urban architecture is usually a product of the collective architectural experience of a people (Massip-Bosch, 2020). However, this has not been the case in Nigeria. The colonialist established neoclassical architecture upon arrival to Nigeria in the late 19th century appropriate for government buildings, railway terminals and ports. This gave way to tropicalized modern architecture in the late 60s. In Abuja, modern architecture established firm roots right from inception as there were broad guidelines accepted for the design of buildings. The experience became richer in the 90s although highly diversified especially with residential buildings. The observation in this study corroborates the earlier reports by Rikko and Gatau (2011).

\subsubsection{Kaduna}

In Kaduna, visible neo-classical buildings include the State Secretariat Complex along Independence Way, Railway Terminal, Lugard House and Lugard Hall as well as the Pediatric Unit of Barau Dikko Teaching Hospital which was built in 1930 (Qurix 2017). The Author maintained that the colonialists soon adopted modern architecture with regional tendencies in the 40s through the 60s. The General Hassan Usman House built in 1948, Lugard Hall extension 1962, and Hamdala Hotel are examples. They represent the old face of Kaduna city as seen in Figure 23.

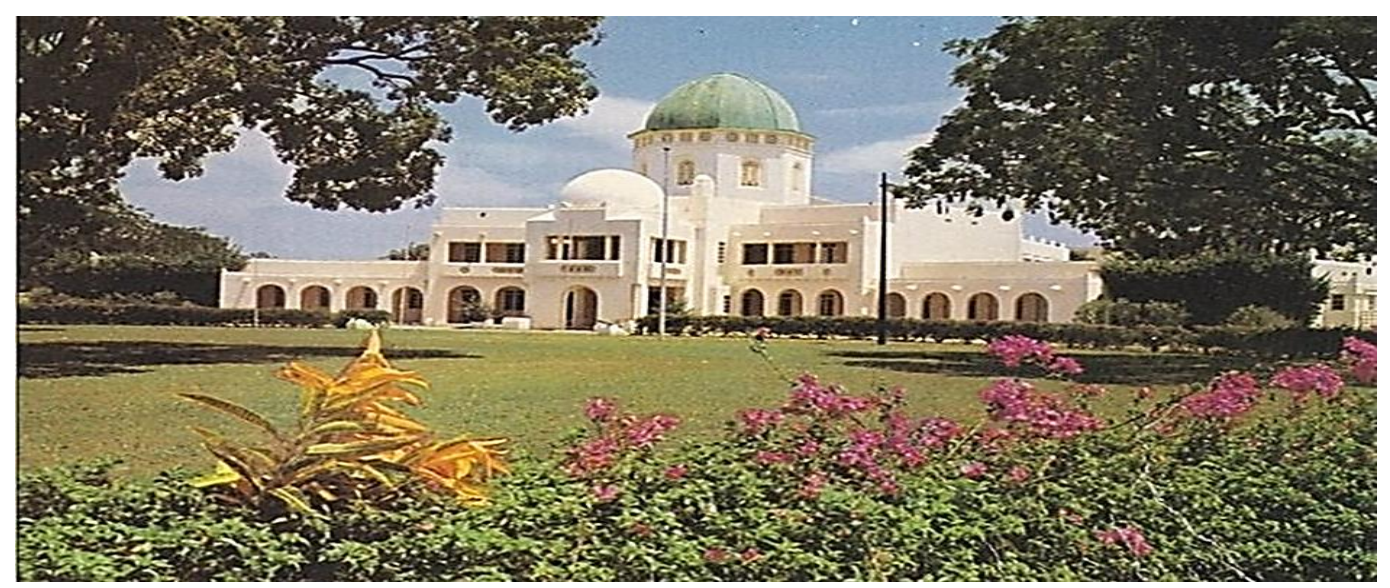

Figure 23. Luggard Hall Kaduna represents the early modern/ classical architecture in Kaduna

The 1970s and 80s witnessed remarkable development of modern buildings such as Ahmed Talib House 1975, New Nigerian Development Company and Turaki Ali House. Meanwhile, the face of residential buildings slowly transformed from Simple Linear to Complex Modern buildings. These have reached cultural and historical vocabulary such as adaptable of heap-sprawling colonial roof and use of neo classical columns. There appears to have been a convergence of thought at the beginning of the 21st century where modern architecture mixed with neo-classical and regional intentions is defining residential buildings, whereas institutional buildings are defined by modern technology and contemporary expressions. 


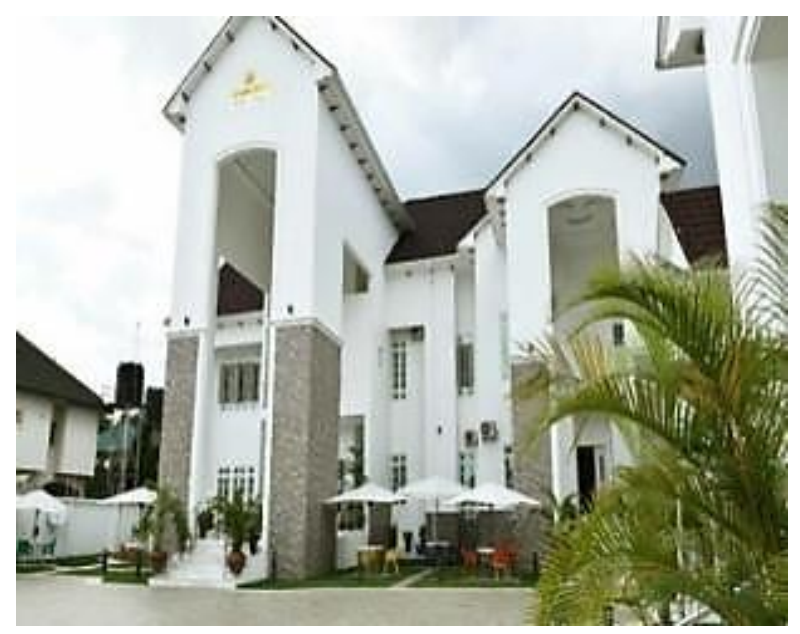

Figure 24. Crystal De White Hotel, Kaduna

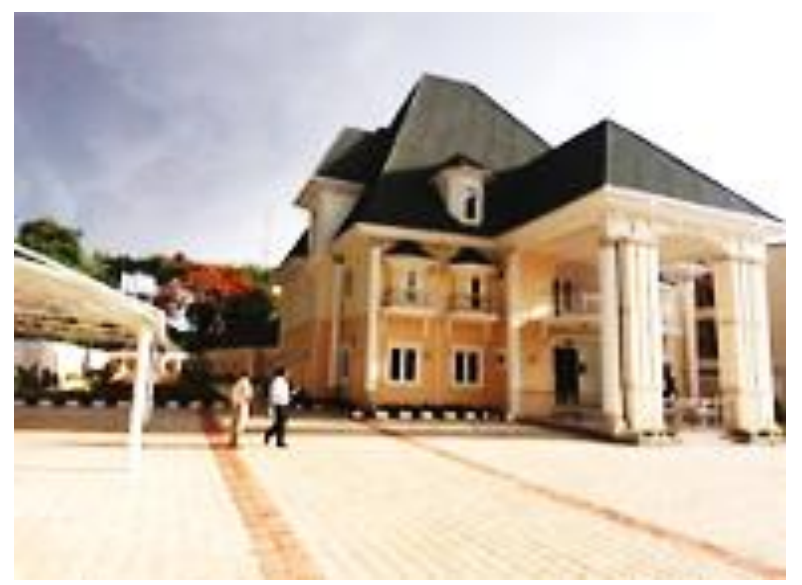

Figure 26. Luxury Houses Unguwar Rimi

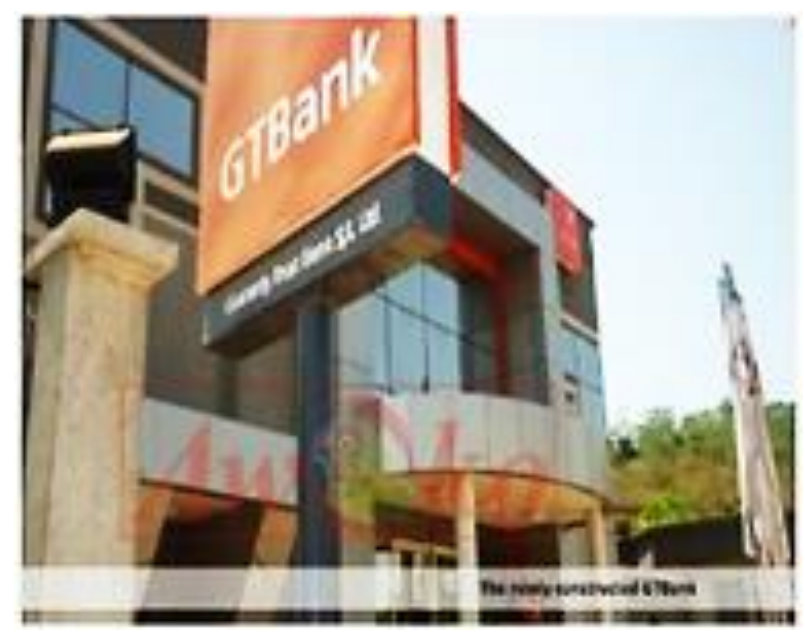

Figure 25. Guarantee Trust Bank, Kaduna

The faces of modern architecture in Kaduna are seen here in Figures 24, 25 and 26 respectively adorned by hotels, commercial banks and private residential buildings. This demonstrates the transformation of architectural outlook from the classical, neoclassical to modern architecture when compared with the structures of the early $60 \mathrm{~s}$ and $70 \mathrm{~s}$. However, this transformation is within the framework of development control standards of heights, setbacks, room sizes and general principles. A situation where modernized development is unevenly spread within less than $2 \mathrm{~km}$ radius in the same city as seen in the case of Kaduna city, leaves much to be desired. Such can hardly allow for the needed national integration. The creation of government reservation areas (GRA) in within the cities across Nigeria, to a great extent, defeats the essence of integration and cannot be seen as a successful policy because of the concentration of quality infrastructure for a few.

\subsubsection{Lagos}

In Lagos, there exist numerous classical and neoclassical buildings that gives the city its architectural and aesthetic outlook. Key among such are the Central Bank Building located in Apapa, Lagos (Figure 27) and some private establishments (Figure 28) who have complied to physical planning regulations in Lagos. 


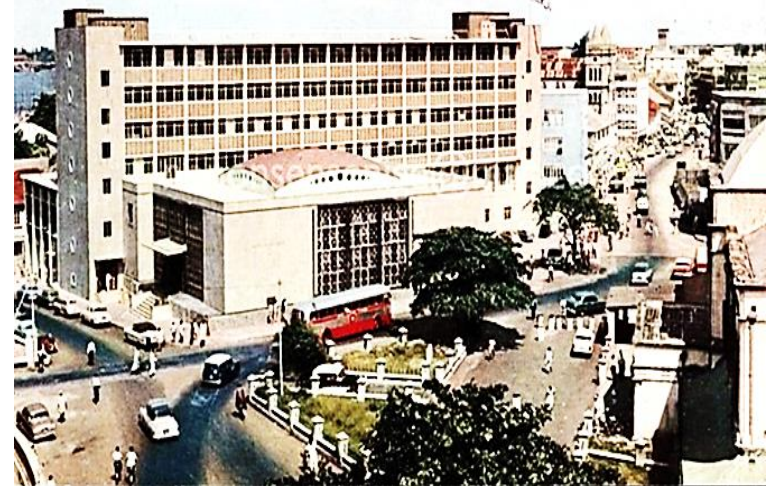

Figure 27. Central Bank Building in Lagos Island represents the Old face of architecture in Lagos

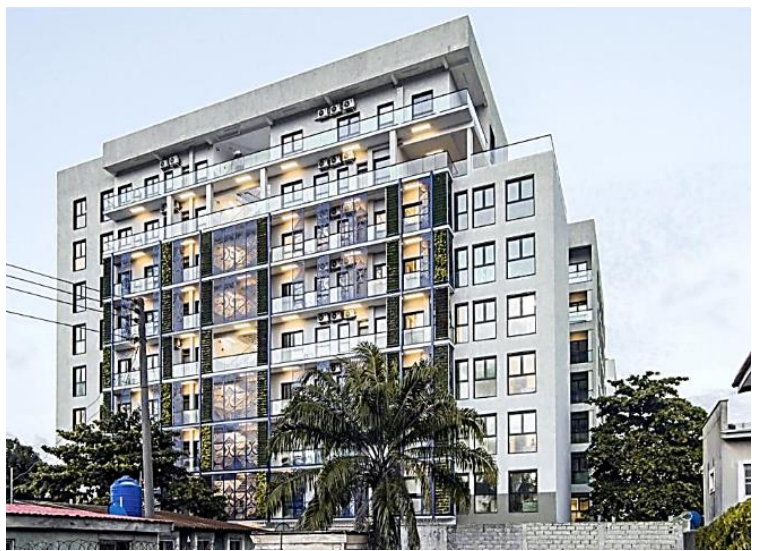

Figure 28. American Intl. School Staff Quarters, Lagos (a face of modern architecture

It is part of the findings to note that both Lagos and Kaduna cities have had to transform over time from classical through neoclassical to modern architecture. Most of the recent areas developed in Lagos such as Victoria Island, Lekki, Banana Island among others are beauty to behold because of the array of modern architectural designs on display.

\subsubsection{Abuja}

Abuja however emerged very recently from the early 90s as a new Federal Capital Territory without necessarily passing through these phases of transformation as its very foundation began on the footing of modern architecture. A drive through the Federal Capital Territory will reveal a city resplendent of variations in modern architectural design. This has been made possible by the very strict regulations, although certain aspects of the city's masterplan have been violated and demolitions are a regular occurrence. Figures 29 and 30 depicts some of the architectural edifices in the Federal Capital Territory.

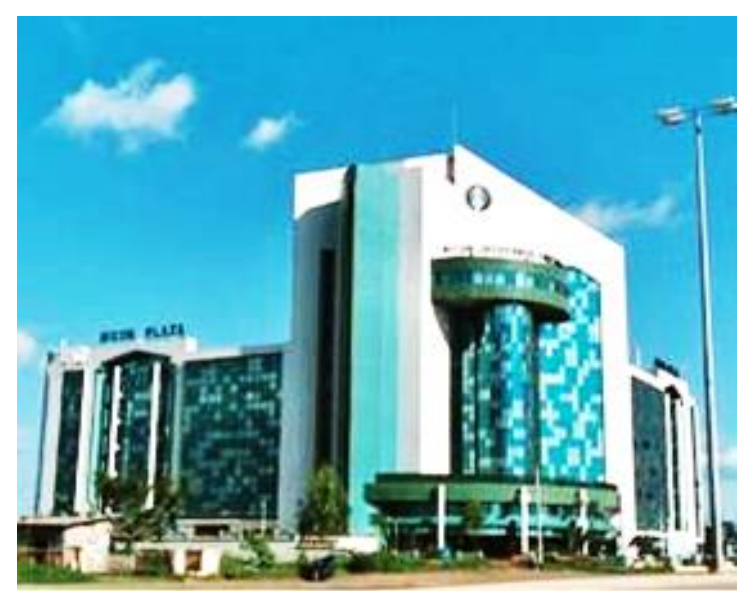

Figure 29. NICON Headquarters, Central Area, Abuja

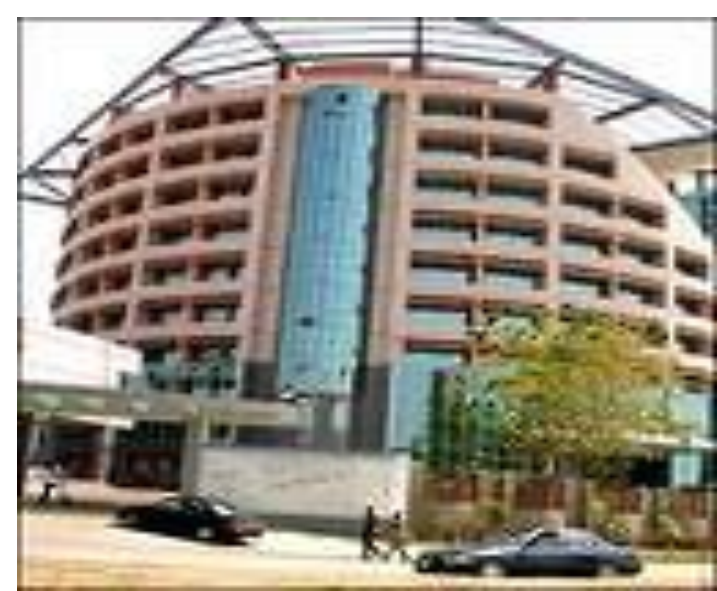

Figure 30. NCC Building Maitama Abuja

\subsection{Urban Management Structures}

In the three cities reviewed, there exist Urban Planning Boards which make policies and are broadly constituted in line with the different facets of urban development. However, their execution 
of development controls does not enjoy the full complement of many experts apart from the basic ones i.e. Planners, Architects and Engineers. Hence, the policy objectives of the Boards or Agencies are hardly met. Similarly, some policy objectives are addressed by other separate agencies which are represented on the Board. For example, environmental issues are addressed by Kaduna Environmental Protection Agency (KEPA) and commercial issues are addressed by Ministry of Commerce and Industries. Both are represented on the KASUPDA Board. It is believed that the development control unit should have experts in environment, economics/commerce, and politics in addition to the technical experts. In that way, the objectives of the Board will be easily achieved. Experts could be seconded from the relevant agencies of state ministries to join the development control unit. This would further unite the policies of such agencies with the objectives of development control. In that way, the development control unit will act as a clearing house to harmonize inputs from various agencies in a round table. Alternatively, different subunits could be created under the development control unit to supervise various aspects while the main unit would harmonize their inputs for approval.

Further, Boards should be strengthened to dispense good governance and should be independent to the extent of planning both the physical and socio-economic environment. They should draw their funding from the state budget as well as Public Private Partnerships (PPPs), although under the supervision of the government. In order words, the cities are required to be micromanaged to be able to attend to the numerous issues that are not explicitly captured in the manuals, but which are clearly at the fore.

\subsection{Ranking of Cities}

It is important to develop city rankings based not just on population but inclusive of infrastructure, security, socio economic activities, crime and poverty levels. Development control mechanisms and the stakeholders who man them should be interested in the way a development index is given to a city. For the same reason, they should integrate these indices in the ranking of cities so as to control the desired objectives. This could help in determining the challenges of resources, and monitoring of the quality of life of urban inhabitants. Key components to be evaluated should include:

1. City size and physical planning

2. City size and health (mortality rate, incidence of disease etc.).

3. City size and public safety (crime rates, accident rates, fire hazards etc.).

4. City size and municipal efficiency.

5. City size and education expenditure.

6. City size and cost of living.

7. City size and public recreation

8. City size and retail facilities

9. City size and family life. 
10. City size and miscellaneous psychological and social characteristics of urban life (community participation, and social contentment).

11. City size and associations.

Now, cities that are considered urbanized by virtue of high populations actually do have high percentages of poor inhabitants and weak infrastructure and may not be said to be developed. Development should be seen from the point of view of aggregation of many indices including components of human security and improved livelihoods that culminates into the peace index. It is worthy of note at this point, that the contrasting outlook of different parts of the same city in terms of development indices may not enable such cities to function optimally as such could undermine the overall interest of the state in question. Kaduna provides a classical example of this anomaly as seen in Figures 8, 10 and 11 compared to Figures 5 and 16.

\subsection{Mega Cities Vs. Satellite Cities}

It has been pointed out that lack of conscious efforts to plan and develop the urban areas lead to formulation of slums and poor environment. However, governments are now making deliberate efforts to expand cities through the development of satellite cities such as Millennium City for Kaduna; Karshi and Kuje for Abuja, and the formation of a Mega Cities in Lagos such as Banana Island as well as Lekki Peninsula among others. It is believed that the development of satellite cities has high potentials in dispersing inhabitants from the city center and should be seen as a good approach. On the other hand, the development of mega cities is likely to have challenges of harmonization of the dynamics of different cities, planning of infrastructure and governance. However, it has the potential of generating urban renewal amongst cities that have been robbed of their aesthetics.

\subsection{Indigenous Settlements vs Cities}

In parts of the studied cities, particularly Abuja (FCT), there exists the phenomenon of indigenous settlements that provide a kind of economic escape from the expensive city life. They are composed of new but unplanned buildings that offer shelter to the majority of workforce that service the city. Houses are interlocked with no defined paths and there is the complete absence of drainage system and solid waste management. The structures look better than those in blighted areas (Figure 5 and Figure 14) already discussed but the official basis of their existence is unfounded. A typical example is Dutsen Alhaji in the FCT (Figure 31). Worse still, the management of the FCT appear to be uninformed about their existence despite housing significant population. Interestingly, residents are captured in the electoral roll and are expected to exercise their voting rights. From the interviews conducted, there appears to be no mention of them in the budgeting process of the FCT administration despite existing within their geographical region. 


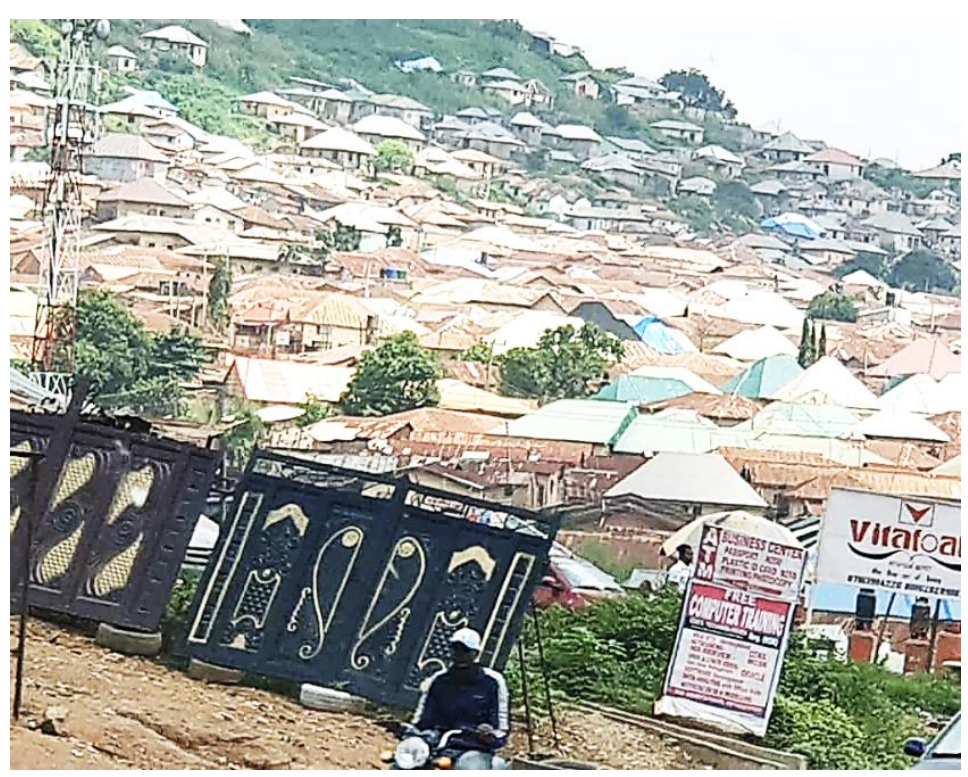

Figure 31. Dutsen Alhaji, Abuja. A soft-landing for expensive city life. (Source: Researcher's field photograph)

\section{Conclusions}

In reviewing urban development in our cities, it has been identified that states have set up Urban Development Agencies which work through development control units to enforce, control and monitor policy objectives of their Boards. The cities reviewed i.e. Kaduna, Abuja and Lagos have certain similarities. They all have functional development control units which are defective in composition of experts necessary to achieve the objectives of development control holistically. The paper has explored leading issues in urban development and has identified that there is a nexus between urbanization and urban development. Specifically, it has been identified that urbanization does not necessarily lead to development though it is often due to the growth of the urban area. It argued that urban development should be seen from the point of view of an aggregation of several indices which include population, architecture, environment, socio-economic activities, security and poverty questions. The aim of these aggregated indices is to improve the quality of life of the urban dweller. The work concludes with some recommendations while looking into the future to repositioning the state of urban development to meet international best practices which is part of the sustainable development goals.

\section{Recommendations}

Given the multifarious problems already identified in the current study areas, it would appear as though the problems of urban development are insurmountable. This is in view of the challenges associated with urban development as highlighted as well as the continued surge in urban population. However, certain bold steps are required by both state and non-state actors to establish structures and appraise existing control mechanisms in order to translate our cities into the desired urban centers they were intended to be. From the foregoing, a comprehensive framework of reengineering that would overhaul the entire urban landscape will be a rational starting point for any 
meaningful intervention. Nevertheless, it is needful to state the need for the development of the city centers with massive infrastructure for sustainable development that keeps urban decay in check. The following is therefore recommended thus;

1. A multi-stake-holder urban management structure

2. Ranking of cities.

3. Legislative provisions and adequate funding for cities.

4. Development and management of mega cities vs. satellite cities.

5. Deliberate social/national integration measures.

6. Resettlement/Integration.

7. Reordering of priority in revenue and funding for critical infrastructure

8. Strengthening of security agencies for effective crime management and social consensus

\section{Conflict of Interest}

The Authors declare no conflict of interest with the publication of this manuscript

\section{Funding}

No funding was received for this work

\section{References}

1. Adama, O. (2018). Urban Imaginaries: Funding Mega Infrastructure Projects in Lagos, Nigeria. GeoJournal. 83, 257-274. https://doi.org/10.1007/s10708-0169761-8

2. Africa Development Bank Group, Groups Urban Development Strategy. Retrieved 5, April, 2016.

3. Aluko, O.E. (2010). The Impact of Urbanization on Housing Development: The Lagos Experience, Nigeria. 3(3): 64-74.

4. Ayedun, C.A., Durodola O.D. and Akinjare O.A. (2011). Ensuring Sustainable Urban Growth and Development in Nigeria Challenges and Strategies. www.bmdynamics.com retrieved 5 April, 2016.

5. Akpu, B., Tanko, A.I., Jeb, D.N. and Dogo, B. (2017). Geospatial Analysis of Urban Expansion and Its Impact on Vegetation Cover in Kaduna Metropolis, Nigeria. Asian Journal of Environment \& Ecology. 3(2), 1-11.

6. Bununu, Y.A., Ludin, A.N.M. and Hosni, N. (2015). City profile: Kaduna. Cities. 49, 53-65.

7. Burgess, E.W., (1925). "The Growth of the city: An introduction to a research project" Chapter 2 in Park, Robert E., Burgess, Ernest W. \& McKenzie, R. D. (1925). “The City: Suggestions for Investigation of Human Behavior in the Urban Environment", University of Chicago Press, Chicago, pp. 47-62.

8. Christaller, W. (1933). An Introduction to Central Place Theory (СPT). Accessed at http://planningtank.com/settlement-geography/central-place-theory-walter-christaller, on October 7, 2020.

9. Christaller, W. (1966). "Central Places in S. Germany", Englewood Cliffs, Prentice Hall in Clark, W.A.V. (2003), “Monocentric to Polycentric: New Urban Forms and Old Paradigms" in Daniels, T. (1999). "When city and country collide: Managing growth in the metropolitan fringe". Island Press, Washington DC.

10. Dano, U.L., Balogun, A., Abubakar, I.R. and Aina, Y.A. (2020). Transformative Urban Governance: Confronting Urbanization Challenges with Geospatial Technologies in Lagos, Nigeria. GeoJournal. 85, 10391056.

11. Drakakis-Smith, D. (1987). The Third World City. London: Methuen \& Co. Ltd. 
12. Duthiers, V. and Kermeliotis. A. (2012). Lagos of the Future: Megacity's ambitious plans. CNN presentation: retrieved on November 30, 2016.

13. Echendu, J.A. (2020). The Impact of Flooding on Nigeria's Sustainable Development Goals. Ecosystem, Health and Sustainability. 6(1). https://doi.org.10.1080/20964129.2020.1791735

14. Ezema, I.C., Ediae, O.J. and Ekhaese, E.N. (2016). Prospects, Barriers and Development Control Implications in the use of Green Roofs in Lagos, Nigeria. Covenant Journal in Research and Built Environment. 4(2), 5470.

15. Heinrich B.S. (2016). Urban Planning Process in Lagos. Slippage Design Service, Lagos pp 28-36.

16. Hoyt, H. (1939). The Structure and Growth of Residential Neighborhoods in American Cities. Washington: Federal Housing Administration, Washington, D.C.

17. Ibrahim, A.A. (2020). 6 Ways that Gulf Cities can Turn Waste into Wealth. Paper presented at the 2020 World Economic Forum (WEF). www.weforum.org/agenda/2020/06/6-ways-that-gulf-cities-can-turn-waste-intowealth/

18. Iweze D.O. (2015). in Usman T.M. and Rufai M.A. (eds): The Impact of Dyeing Industry on the SocioEconomic Transformation of Hausa Land C. 1500 - 180 Aboki publishers pp. $29-40$.

19. Jelili, M.O., Akinyode, B.F. and Ogunleti, A. (2020). Land Pooling and Urban Renewal in Lagos State: A Narative Inquiry into Isale Gangan Project. Urban Forum. https://doi.org/10.1007/s12132-020-09405-5

20. Jose, I.B., Luca, D., Carlo, L. and Niall, M. (2004). Modeling Future Urban Scenarios in Developing Countries: an application Case Study in Lagos, Nigeria. Environmental and Planning B: Planning and Design. 32, 6584.

21. Kadafa, A.A. (2016). Solid Waste Management Practice in Abuja, Nigeria. Journal of Pollution Effects and Control. 4(2, Suppl). https://doi.org/10.4172/2375-4397.C1.002

22. Lamudi (2014). In ourfuturecities.com. “Lagos State Amends Urban, Regional Planning and Development Law". Article accessed on October 7, 2020.

23. Makoni, F.S., Ndamba, J., Mbati, P.A. and Manase, G. (2004). Impact of Waste Disposal on Health of a Poor Urban Community in Zimbabwe. East Africa Medical Journal. 81(8), 422-426. https://doi.org/10.4314/eamj/v81i8-9204

24. Massip-Bosch, E. (2020). Architecture and the City: A Relational Design Primer. Public lecture at Institute of Advanced Architecture of Catalonia (IAAC). December 10, 2019.

25. National Bureau of Statistics NBS) (2012). Nigeria Poverty Profile. Retrieved April 14, 2016; Population Density in Nigeria www.tradingeconomics.com retrieved on April 16, 2016.

26. National Bureau of Statistics, NBS (2015). Lagos State Information. Archived from the original document. Assessed on September 30, 2020.

27. Nekabari, J.N. and Aguiyi, F. (2012). The Urban Poor and Housing in Nigeria 1999-2007: A Case Study of the Urban Poor and Housing Programmes in Port Harcourt, Rivers State. Journal of Language, Technology and Entrepreneurship in Africa. 3(2), 142-171.

28. Nigerian Urban and Regional Planning Law Decree 88, 1992. The Nigeria Institute of Town Planners, Lagos.

29. Ogundele, F.O., Ayo, O., Odewumi, S.G. and Aigbe, G.O. (2011). Challenges and Prospects of Physical Development Controls: A Case Study of Festac Town, Lagos, Nigeria. African Journal of Political Science and International Relations. 5(4), 174-178.

30. Ogunleye, O., Owolabi, O. and Mubarak, M. (2018). Population Growth and Economic Growth in Nigeria: An Appraisal. International Journal of Management, Accounting and Economics. Vol. 5, No. 5, ISSN 23832126 (Online). 
31. Olawale, Y.I. (2020). Religion and Identity Politics in Nigeria. New Trends in Social and Liberal Sciences (NETSOL). 5(1), 1-17. DOI: 10.24819/netsol2020.01

32. Olufemi, O. and Ambrose, A. (2018). Development Control Regulations Compliance: Paradigm Change to Reinvent Disrupted Public Spaces and make Future Great Place in Ado-Ekiti, Nigeria. Civil Engineering and Architecture. 6(1), 1-17. DOI: 10.13189/cea.2018.060101

33. Olukanni, D.O., Aipoh, A.O. and Kalabo, I.H. (2018). Recycling and Recuse Technology: Waste to Wealth Initiative in a Private Tertiary Institution in Nigeria. Recycling. 3(3), 44. https://doi.org/10.3390/recycling3030044

34. Oluwafemi, A.O., Muyiwa, E. and Hakeem, B.B. (2018). The Realities of Lagos Urban Development Vision on Livelihoods of the Urban Poor. Journal of Urban Management. 7(1), 21-31

35. Onuminya, T.O. and Nze, E.C. (2017). An Appraisal of Waste Management in Lagos Metropolis: ACase Study of Lagos State Waste Management Authority (LAWMA). Nigerian Journal of Pure and Applied Science. 30(3), 3104-3108.

36. Osaghae, E.E. and Suberu, R.T. (2005). A History of Identities, Violence, and Stability in Nigeria. Centre for Research on Inequality, Human Security and Ethnicity (CRISE) Working Paper No. 6. University of Oxford, UK.

37. Owusu, G. (2010). Social Effects of Poor Sanitation and Waste Management on Poor Urban Communities: A neighborhood Specific Study of Sabom Zongo, Accra. Journal of Urbanism. 3(2), 145-160. https://doi.org/10/1080/17549175.2010.502001

38. Ozo, A.O. (2009). Urban Change and Conflict in the Traditional Character of an African City: The Example of Benin City, Nigeria. Planning Perspectives. 24(4), 485-507. https://doi.org/10.1080/02665430903145713

39. PopulationStat.com (2020). Lagos, Nigeria Population. Assessed on September 30, 2020 (online).

40. Price, K.R. and Vojinovi, Z. (2011). “Urban Hydroinformatics: Data, Models, and Decision Support for Integrated Urban Water Management. IWA Publishing. p. 492.

41. Qurix W.B. (2017). “The Future of Urban Development in Nigeria and the Effect of Development Control Mechanism. A Distinguished Public Lecture delivered at the Nigerian Defence Academy (NDA) Kaduna. On $11^{\text {th }}$ July 2017 at Mahmud Yakubu Hall Permanent Site, Afaka.

42. Qurix W.B. (1989). The Tall Office and The African City Center. Paper presented at the Conference on Alternative Development Strategies for Africa University of Dar Es Salam, Tanzania.

43. Rikko, L.S. and Gwatau, D. (2011). The Nigerian Architecture: Trends in Housing Development. Journal of Geography and Regional Planning. 4(5), 273-278.

44. Sridhar, M.K.C. and Hammed, T.B. (2014). Turning Waste to Wealth in Nigeria: An Overview. Journal of Human Ecology. 46(2), 195-203. DOI: 10.1080/09709274.2014.11906720

45. Turner II, B.L., Clark, W.C., Kates, R.W., Richards, J.F., Mathews, J.T., and Meyer, W.B. (1990). “The Earth as Transformed by Human Action".

46. Usman, M.B., Sanusi, Y.A. and Musa, D. (2017). Physical and commuting characteristics of selected periurban settlements in Kaduna, Kaduna State, Nigeria. Journal of Geography and Regional Planning. 10(11), 317-329

47. Wapwera, S.D. and Gajere, J.K. (2017). Ethnoreligious Urban Violence and Residential Mobility in Nigerian Cities: The Kaduna Experience. Urban Studies Research. Volume 2017. https://doi.org/10.1155/2017/4624768

48. Wendell, E.P. (2003). The Public Menace of Blight: Urban Renewal and the Private Use of Eminent Domain. Yale Law \& Policy Review. 21(1), 1-52 


\section{Interviews:}

1. Bala Mohammed Raji. A resident of Narayi for over 30 years and a practicing Architect in Kaduna. Interviewed on 22 May 2017 in Kaduna.

2. Atiyaye Barnabas. A resident of Kaduna and practicing Town Planner. Interviewed in Kaduna on 22 May 2017 